\title{
Seasonal shifts in export of DOC and nutrients from burned and unburned peatland-rich catchments, Northwest Territories, Canada
}

\author{
Katheryn Burd ${ }^{1}$, Suzanne E. Tank ${ }^{2}$, Nicole Dion ${ }^{3}$, William L. Quinton ${ }^{4}$, Christopher Spence ${ }^{5}$, Andrew J. Tanentzap ${ }^{6}$, \\ and David Olefeldt ${ }^{1}$ \\ ${ }^{1}$ Department of Renewable Resources, University of Alberta, Edmonton, T6G 2R3, Canada \\ ${ }^{2}$ Department of Biological Sciences, University of Alberta, Edmonton, T6G 2E9, Canada \\ ${ }^{3}$ Water Resources Department, Government of Northwest Territories, Yellowknife, X1A 2L9, Canada \\ ${ }^{4}$ Centre for Cold Regions and Water Science, Wilfred Laurier University, Waterloo, N2L 3C5, Canada \\ ${ }^{5}$ National Hydrology Research Centre, Environment and Climate Change Canada, Saskatoon, S7N 3H5, Canada \\ ${ }^{6}$ Ecosystems and Global Change Group, Department of Plant Sciences, University of Cambridge, \\ Cambridge, CB2 3EA, UK
}

Correspondence: David Olefeldt (olefeldt@ualberta.ca)

Received: 7 May 2018 - Discussion started: 15 May 2018

Revised: 18 July 2018 - Accepted: 31 July 2018 - Published: 22 August 2018

\begin{abstract}
Boreal peatlands are major catchment sources of dissolved organic carbon (DOC) and nutrients and thus strongly regulate the landscape carbon balance, aquatic food webs, and downstream water quality. Climate change is likely to influence catchment solute yield directly through climatic controls on run-off generation, but also indirectly through altered disturbance regimes. In this study we monitored water chemistry from early spring until fall at the outlets of a $321 \mathrm{~km}^{2}$ catchment that burned 3 years prior to the study and a $134 \mathrm{~km}^{2}$ undisturbed catchment. Both catchments were located in the discontinuous permafrost zone of boreal western Canada and had $\sim 60 \%$ peatland cover. The two catchments had strong similarities in the timing of DOC and nutrient yields, but a few differences were consistent with anticipated effects of wildfire based on peatland porewater analysis. The 4-week spring period, particularly the rising limb of the spring freshet, was crucial for accurate characterization of the seasonal solute yield from both catchments. The spring period was responsible for $\sim 65 \%$ of the seasonal DOC and nitrogen and for $\sim 85 \%$ of the phosphorous yield. The rising limb of the spring freshet was associated with high phosphorous concentrations and DOC of distinctly high aromaticity and molecular weight. Shifts in stream DOC concentrations and aromaticity outside the early spring period were consistent with shifts in relative streamflow con-
\end{abstract}

tribution from precipitation-like water in the spring to mineral soil groundwater in the summer, with consistent relative contributions from organic soil porewater. Radiocarbon content $\left({ }^{14} \mathrm{C}\right)$ of DOC at the outlets was modern throughout May to September (fraction modern carbon, fM: 0.99-1.05) but likely reflected a mix of aged DOC, e.g. porewater DOC from permafrost (fM: 0.65-0.85) and non-permafrost peatlands (fM: 0.95-1.00), with modern bomb-influenced DOC, e.g. DOC leached from forest litter (fM: 1.05-1.10). The burned catchment had significantly increased total phosphorous (TP) yield and also had greater DOC yield during summer which was characterized by a greater contribution from aged DOC. Overall, however, our results suggest that DOC composition and yield from peatland-rich catchments in the discontinuous permafrost region likely is more sensitive to climate change through impacts on run-off generation rather than through altered fire regimes.

\section{Introduction}

Catchment export of terrestrially derived dissolved organic carbon (DOC) and nutrients represent significant losses from terrestrial ecosystems and further regulate functions of down- 
stream aquatic ecosystems, including primary productivity, light conditions, heterotrophic respiration, greenhouse gas emissions, and availability of contaminants such as mercury (Karlsson et al., 2009; Tranvik et al., 2009; Braaten et al., 2014). Peatlands are important sources of DOC and nutrients in boreal catchments, due to large stores of soil organic matter in peatlands that often are hydrologically well connected to stream networks (Laudon et al., 2011). The discontinuous permafrost zone of boreal western Canada contains some of the largest and most extensive peatlands in the circumboreal region (Tarnocai et al., 2009), and the region is experiencing rapid climate change. In order to anticipate impacts of climate change on catchment DOC and nutrient export patterns in boreal western Canada, it is likely required to take into account both regional characteristics that influence catchment hydrology, e.g. the relatively dry climate and the presence of permafrost, and the role of disturbances, e.g. an intensified fire regime (Flannigan et al., 2009).

Water chemistry of boreal streams exhibits large variability both in time and space due to differences in hydrological connectivity of various catchment water sources. The relative catchment coverage of peatlands with thick organic soils, and upland forests with mineral soils, is a first-order control on stream water chemistry in boreal regions (Laudon et al., 2011). Peatlands often act as major sources of dissolved organic matter due to the direct hydrological connectivity of their large stores of soil organic matter and can dominate cumulative annual catchment DOC export if peatland coverage exceeds $10 \%$ (Ågren et al., 2008). The temporal variability in stream water chemistry is often associated with variability in catchment run-off generation, where the relationships between chemistry and run-off can be used to infer hydrological processes and indicate the relative contribution from various water sources under different conditions (Godsey et al., 2009; Ågren et al., 2014). For example, during periods of high run-off it has been found that peatland run-off generally is diluted while run-off generation in upland forest riparian zones leads to hydrological connection with the shallow organic soil, which causes increased stream concentrations of DOC and nutrients (Carey, 2003; Ågren et al., 2008; Ledesma et al., 2017). As such it is crucial to monitor stream water chemistry during high-run-off periods, including the spring freshet in high-latitude regions, in order to accurately characterize the cumulative catchment export of DOC and nutrients to downstream ecosystems (Finlay et al., 2006).

The chemical composition of dissolved organic matter in streams can indicate both the contribution of distinct sources to DOC and nutrient export (Wickland et al., 2007), as well as influence its susceptibility to microbial and photochemical processing or flocculation in downstream aquatic ecosystems (Sulzberger and Durisch-Kaiser, 2009; von Wachenfeldt et al., 2009; Cory and Kaplan, 2012). Easy-to-measure spectrophotometric indicators of bulk DOC aromaticity (e.g. specific UV absorbance, SUVA, at $254 \mathrm{~nm}$; Weishaar et al., 2003) and average molecular size (e.g. spectral slope be- tween 275 and 295 nm; Helms et al., 2008; Fichot and Benner, 2012) have been found to be useful for both differentiating catchment water sources and indicating microbial and photochemical reactivity. While DOC derived from organic soils, including peat and riparian soils, generally has higher aromaticity and molecular weight than DOC derived from mineral soil groundwater sources (Kaiser and Kalbitz, 2012), there is still a wide variability depending on the degree of soil humification, type of vegetation litter, season, and fire history (Wickland et al., 2007; Hugelius et al., 2012; Olefeldt et al., 2013c; O'Donnell et al., 2016). Different catchment DOC sources may also vary in terms of radiocarbon $\left({ }^{14} \mathrm{C}\right)$ age (Raymond et al., 2007) and thus provide another means to differentiate between sources contributing to catchment DOC export. However, DOC radiocarbon age further (i) indicates whether links between terrestrial and aquatic biogeochemistry predominately act on short or long timescales (Campeau et al., 2017) and (ii) provides evidence in permafrost regions of downstream mobilization of previously frozen soil organic matter (Spencer et al., 2015). Shifts in stream DOC composition may thus be as important for downstream ecosystems as a shift in catchment DOC export magnitude, and both aspects of catchment DOC export are potentially influenced directly by climate change and indirectly e.g. though impacts of wildfire.

Approximately $25 \%$ of treed permafrost-affected peat plateaus have burned during the last 30 years in the discontinuous permafrost zone of western boreal Canada (Gibson et al., 2018). The fire regime in this region is thus already showing signs of increased occurrence due to climate change, and a $50 \%$ increase in fire occurrence is projected by the end of the century (Flannigan et al., 2009). While fire is generally found to cause increased catchment export of total phosphorous (TP) in the boreal biome, observed impacts of fire on DOC and total dissolved nitrogen (TDN) export include increases, decreases, and no change (Carignan et al., 2000; Lamontagne et al., 2000; McEachern et al., 2000; Betts and Jones, 2009; Marchand et al., 2009). Wildfire does not cause complete combustion of peatland soils in the discontinuous permafrost zone in boreal western Canada, given the significant depth of the peat deposits. However, wildfire in permafrost-affected peat plateaus has been shown to cause significantly deepened seasonally thawed peat layer above the permafrost, i.e. the active layer (Gibson et al., 2018), which suggests that peatland run-off in the years following fire is routed through deeper, older peat layers. As such, catchments in this region may exhibit a characteristic response to wildfire with regards to DOC composition.

The objective of this study was (i) to improve our understanding of controls on catchment DOC and nutrient export in a region with extensive permafrost-affected peatland complexes and (ii) to assess potential impacts of recent wildfires. We monitored DOC and nutrient export from two catchments from the early spring freshet to late fall, one of which was almost completely burned 3 years prior to the study, 
and further collected peatland pore water throughout the study within burned and unburned peatland sections. Highfrequency records of stream chemistry from spring to fall are uncommon from high-latitude catchments, and from the study region in particular, given the practical challenges of working in remote locations. We hypothesized (i) low overall catchment yields of DOC and nutrients when compared to other boreal peatland-rich regions due to the relatively dry climate and (ii) that a majority of yields were associated with the spring freshet. We further hypothesized modest impacts of wildfire on the magnitude of catchment DOC yields, but increased DOC aromaticity and radiocarbon age due to deepened flow paths within burned peat plateaus.

\section{Methods}

\subsection{Catchment descriptions}

Scotty Creek (SC) and Notawohka Creek (NW) drain catchments located in the discontinuous permafrost zone of Canada's western boreal forest (Fig. 1). The SC outlet at the Liard Highway $\left(61^{\circ} 24 \mathrm{~W}, 121^{\circ} 26 \mathrm{~N}\right)$ has a $134 \mathrm{~km}^{2}$ catchment that has not been affected by any major fires in the last 60 years. The NW outlet at the Mackenzie Highway $\left(61^{\circ} 08 \mathrm{~W}, 120^{\circ} 17 \mathrm{~N}\right)$ has a $321 \mathrm{~km}^{2}$ catchment that was > $90 \%$ burned in 2013 (Northwest Territories Fire Scar Map, 2013). The fire burned a total area of $967 \mathrm{~km}^{2}$ between late June and mid-August, thus likely having variable fire severity within the fire scar (Walker et al., 2018). Both catchments are located in the Taiga Plains Mid-Boreal Ecoregion within the Mackenzie Basin (Ecosystem Classification Group, 2007), which is characterized by short summers and long, dry winters (Quinton et al., 2009). Mean annual temperature is $-3.5^{\circ} \mathrm{C}$ and mean annual precipitation is $350 \mathrm{~mm}$, with the majority falling as snow (Meteorological Services of Canada, 2002; Ecosystem Classification Group, 2007; Quinton et al., 2009). The bedrock of the catchments is dominated by sedimentary shale, limestone, and dolomite rocks formed during the Devonian period (Wheeler et al., 1996), while surface geology is dominated by thin to thick tills and glaciolacustrine fine-grained deposits formed during glacial retreat after the last glacial maximum (Aylsworth et al., 2000). Both catchments are flat to gently undulating, with $<50 \mathrm{~m}$ difference between outflow and maximum elevation (248-295 and 263-300 m a.s.l. for SC and NW, respectively). The ecoregion is co-dominated by (i) mixed-wood forests of trembling aspen (Populus tremuloides) and white spruce (Picea glauca) in well-drained locations and (ii) extensive lowland peatlands where peat deposits can be up to $8 \mathrm{~m}$ thick (Quinton et al., 2009). The peatlands are a mosaic of permafrost peat plateaus, permafrost-free thermokarst bogs, and channel fens (Quinton et al., 2009; Wieder and Vitt, 2010). Peat plateaus are relatively dry and dominated by black spruce (Picea mariana), Labrador tea (Rhododendron groenlandicum), and a variety of lichen species; thermokarst bogs have a water table 5 to $40 \mathrm{~cm}$ below the surface and support Sphagnum spp. mosses and low shrubs, while channel fens have a persistent water table above the soil surface and vary from being dominated by sedges and other tall graminoids to being dominated by shrubs mostly from the genus Betula (Quinton et al., 2009; Wieder and Vitt, 2010). Neither thermokarst bogs nor channel fens burn readily well as they are wetter and lack trees; hence, these ecosystems were largely unaffected by the fire that burned the Notawohka Creek catchment.

We used digital elevation models and satellite image interpretation to delineate the stream networks and the catchment limits. A supervised land cover classification (ArcGIS 2017, ESRI, Redlands, CA, USA) of the SC and NW catchments was carried out using publicly available MODIS satellite imagery taken before the 2013 fire (Zoom Earth, https: //zoom.earth/, last access: April 2017). Easily distinguishable spectral signatures were utilized to identify four land cover classes: (1) open water, (2) upland mixed-wood forests, (3) channel fens, and (4) peat plateau and thermokarst bog complexes (Fig. 2). Image resolution was too coarse to further separate peat plateaus and thermokarst bogs. The two catchments had similar proportional contributions from different land cover classes; both had $\sim 60 \%$ peatland coverage dominated by peat plateau and thermokarst bog complexes (Fig. 2). The NW catchment had more open water, and a greater proportion of catchment run-off passes through a series of lakes.

\subsection{Catchment discharge and run-off}

Air pressure and pressure at the bottom of the water column were continuously monitored at $1 \mathrm{~h}$ intervals with $\mathrm{HOBO}$ pressure loggers (Onset, Bourne, MA, USA) from 29 April to 9 September 2016 at the SC and NW catchment outlets. The continuous water stage record was verified by taking stage measurements at stationary staff gauges throughout the study period. The rating curve for estimating hourly discharge at the NW outlet was based on seven manual measurements of discharge (SonTek Flowtracker Handheld ADV, San Diego, CA, USA). Discharge was estimated using the velocity-area method, where stream velocity at $60 \%$ depth was multiplied by cross-sectional areas at 10 locations along a transect spanning the width of the stream (Shaw, 1994). Discharge was measured both during peak spring conditions and summer base flow conditions, and the resulting rating curve had an $R^{2}$ of 0.96 . We estimated an hourly discharge record for the study period using the rating curve and the hourly record of stream stage. Issues with ice damming in the channel during early spring made the rating curve inappropriate, and instead we estimated hourly discharge through linear interpolation between manual discharge measurements from the start of the study until 7 May. Discharge at the SC outlet has been monitored by Water Survey of Canada since 1995 (wateroffice.ec.gc.ca, last access: 16 August 2018) (Fig. 3), 


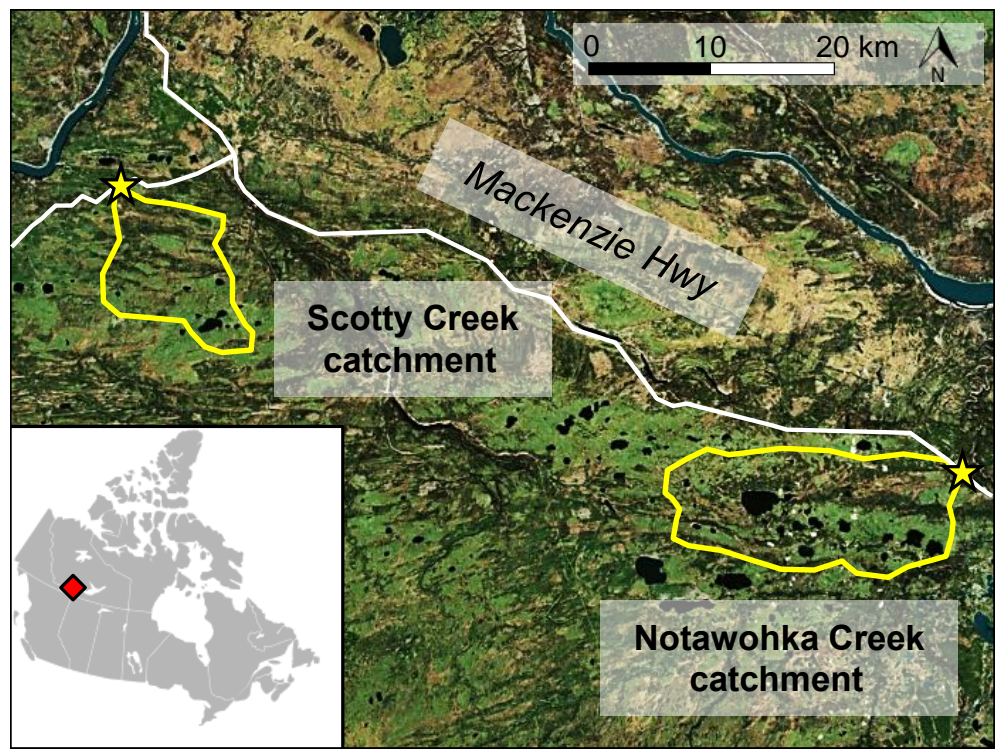

Figure 1. Scotty Creek and Notawohka Creek catchments in the discontinuous permafrost zone of boreal western Canada. Sampling locations at outlets indicated by yellow stars. Photo source: Zoom Earth MODIS Satellite.

but we also measured stream discharge at the SC outlet on seven occasions during the study period to ensure consistency with the NW discharge data. Our discharge measurements at SC were well correlated and had minimal offset when compared to the Water Survey of Canada record $\left(R^{2}=0.99\right)$. Catchment run-off $\left(\mathrm{mm} \mathrm{d}^{-1}\right)$ was calculated by dividing the daily discharge rate by catchment area.

\subsection{Monitoring of water chemistry and catchment solute yields}

Water chemistry at SC and NW outlets was monitored using a combination of grab samples for nutrient and DOC analysis, as well as continuous measurements of electrical conductivity (EC), temperature, and absorbance over the full UV-visible (UV-vis) spectra. Grab samples were collected on 16 occasions between 29 April and 9 September 2016, with eight samples collected in the first month. Two $60 \mathrm{~mL}$ samples were taken at each occasion, which were filtered immediately through $0.7 \mu \mathrm{m}$ nominal pore size glass fibre filters (Grade GF/F, Whatman) into amber glass bottles. Samples were acidified with $0.6 \mathrm{~mL} 2 \mathrm{~N} \mathrm{HCl}$ in order to reduce $\mathrm{pH}$ to $<2$ and thus prevent further microbial activity during transport to the laboratory. An additional $4 \mathrm{~mL}$ filtered, but not acidified, sample was transferred to a $1 \mathrm{~cm}$ pathlength quartz cuvette and analysed for UV-vis absorbance between 230 and $600 \mathrm{~nm}$ using a field portable spectrophotometer (Flame-DA-CUV-UV-VIS light source and Flame-S spectrophotometer, Ocean Optics, Dunedin, FL, US). Acidified samples were analysed within 8 days of collection for concentrations of DOC and total dissolved nitrogen on a TOC-L combustion analyser with a TNM-L module (Shi- madzu, Kyoto, Japan), using four injections where the average standard deviation for injections of the same sample was $0.07 \mathrm{mg} \mathrm{C} \mathrm{L}^{-1}$ and $0.008 \mathrm{mg} \mathrm{N} \mathrm{L}^{-1}$. Standard concentration solutions and blanks (Milli-Q water) were included in each run to ensure accuracy and to avoid analytical drift. An additional eight samples were analysed photometrically $(690 \mathrm{~nm})$ for total phosphorous and total dissolved phosphorous (TDP) concentrations through the stannous chloride method (Standard Method 4500-P:D).

Continuous measurements ( $4 \mathrm{~h}$ intervals) of decadal absorbance $\left(\mathrm{cm}^{-1}\right)$ between 200 and $700 \mathrm{~nm}$, every $2.5 \mathrm{~nm}$, began on 29 April at both catchment outlets using spectro::lyser ${ }^{\mathrm{TM}}$ (s::can Messtechnik GmbH, Vienna, Austria). The instruments were adapted for water with high absorbance with narrow $5 \mathrm{~mm}$ path lengths and were outfitted with automatic brushes that cleaned the lenses 1 min before every measurement. Unfortunately, the automatic brush on the instrument at the SC outlet was damaged a few days after being deployed due to upstream ice break-up. The instrument was restored on 19 May, but lens fouling became an issue and data after 21 June were discarded. The instrument at the NW outlet functioned properly until 17 August, when there was a battery malfunction which prevented further data collection. Quality of the spectro::lyser data was checked by comparison with UV-vis data from grab samples analysed on the field portable UV-vis instrument. Agreement between the spectro::lyser and grab sample data required correction of the spectro::lyser data for turbidity. Following common practice, turbidity was assumed to cause light scattering independent of wavelength, while absorbance of dissolved organic matter was assumed to have negligible absorbance at wavelengths $>550 \mathrm{~nm}$. Hence, the average absorbance at wavelengths be- 
(a) Scotty Creek catchment

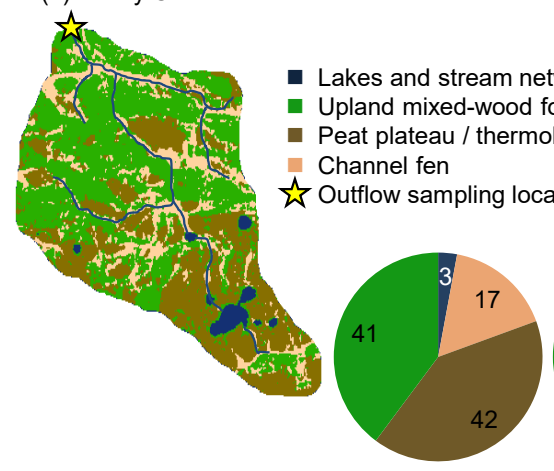

(b) Notawohka Creek catchment

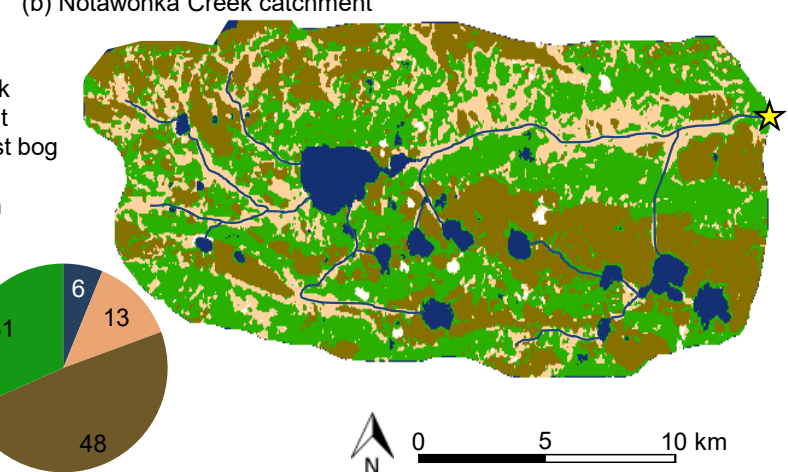

Figure 2. Land cover distribution and stream networks within (a) Scotty Creek and (b) Notawohka Creek catchments. Land cover classification was done through supervised classification using maximum likelihood methodology. Pie charts indicate the percent coverage of each land cover type within each catchment.

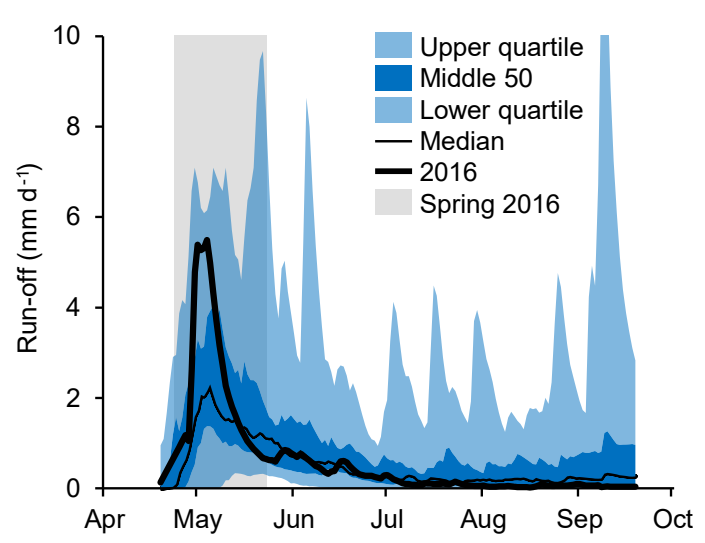

Figure 3. Comparison of the 2016 hydrograph with the historical record from 1995 to 2015 at the Scotty Creek outlet. Historical runoff data maintained by Water Survey of Canada.

tween 550 and 700 was subtracted from the full spectro::lyser UV-vis absorbance spectra (Green and Blough, 1994). Correlation between corrected absorbance from the spectro:lysers and absorbance of grab samples at $254 \mathrm{~nm}$ had an $R^{2}$ of 0.95 with $<5 \%$ offset. Continuous measurements ( $1 \mathrm{~h}$ intervals) of temperature and electrical conductivity were logged at both outlets throughout the study period using HOBO freshwater conductivity loggers (Onset, Bourne, MA, USA). The continuous EC record was checked by comparison against manual EC measurements taken during each sampling occasion (YSI Professional Plus multiparameter water quality instrument, Yellow Springs, Ohio, USA).

We assessed relative DOC aromaticity and average molecular weight using the specific UV absorbance at $254 \mathrm{~nm}$ (SUVA, $\mathrm{L} \mathrm{mg} \mathrm{C}^{-1} \mathrm{~m}^{-1}$ ) and spectral slope between 275 and $295 \mathrm{~nm}\left(S_{275-295}, \mathrm{~nm}^{-1}\right)$, respectively. The SUVA was calculated for grab samples by dividing decadal absorbance at $254 \mathrm{~nm}\left(\mathrm{~cm}^{-1}\right)$ with DOC concentration $\left(\mathrm{mg} \mathrm{CL}^{-1}\right)$, mul- tiplied by 100 (Weishaar et al., 2003). A higher SUVA indicates higher DOC aromaticity. $S_{275-295}$ was estimated on data from the spectro::lyser using a linear fit of the loglinearized spectra between 275 and $295 \mathrm{~nm}$ (Fichot and Benner, 2012). $S_{275-295}$ has been inversely linked to average molecular weight (Obernosterer and Benner, 2004; Helms et al., 2008).

Daily catchment yield of DOC, TDN, TDP, and TP (mass $\mathrm{m}^{-2} \mathrm{~d}^{-1}$ ) was estimated by multiplying catchment run-off $\left(\mathrm{mm} \mathrm{d}^{-1}\right)$ with solute concentrations that were linearly interpolated for periods between each grab sample. $\mathrm{Cu}-$ mulative solute yield was calculated for the rising limb of the spring freshet, the 4-week spring period, and for the entire study period.

\subsection{Endmember mixing analysis to determine streamflow contributions}

A hydrograph separation was carried out for both SC and NW streamflow using three potential water sources as endmembers: organic soil porewater, mineral soil groundwater, and precipitation-like water. We chose to use $A_{254}$ and EC as the two tracers for the hydrograph separation. We assumed conservative mixing for both $A_{254}$ and EC, which implies an overall negligible influence of processes like photodegradation and solute precipitation. High-frequency data were available for both $A_{254}$ and EC for periods when the spectro::lysers were functioning, while $A_{254}$ from grab samples were used when spectro::lyser data were missing. The organic soil porewater endmember was characterized based on porewater that was collected from different peatland ecosystems in the region throughout the 2016 summer (see below). While the organic soil porewater endmember was characterized using peatland porewater $\left(A_{254}: 3.0 \pm 0.5 \mathrm{~cm}^{-1}[ \pm 95 \% \mathrm{CI}], \mathrm{EC}: 55 \pm 10 \mu \mathrm{S} \mathrm{cm}^{-1}\right)$, it was assumed to also be representative of run-off generated in riparian zones of upland forests during very wet periods 
when run-off is routed through shallow organic soils (Seibert et al., 2009). Such shallow riparian organic soil porewater has been found to have similar characteristics as peatland porewater in other boreal regions, with $A_{254}>1.7 \mathrm{~cm}^{-1}$ and $\mathrm{EC}<110 \mu \mathrm{S} \mathrm{cm}^{-1}$ (Jantze et al., 2015; Kothawala et al., 2015). Mineral groundwater and precipitation-like water sources were characterized using published values from studies in the same region (Hayashi et al., 2004; Fraser et al., 2001). The precipitation-like water source was thus assumed to have $A_{254}$ of $0.05 \pm 0.03 \mathrm{~cm}^{-1}$ and EC of $15 \pm 10 \mu \mathrm{S} \mathrm{cm}^{-1}( \pm 95 \% \mathrm{CI})$ while mineral soil groundwater was assumed to have $A_{254}$ of $0.25 \pm 0.10 \mathrm{~cm}^{-1}$ and EC of $325 \pm 175 \mu \mathrm{S} \mathrm{cm}^{-1}$. The flow separation of three endmembers and two tracers was solved using Eqs. (1)-(3) (Christopherson and Hooper, 1992):

$$
\begin{aligned}
& R_{\mathrm{T}}= R_{\mathrm{O}}+R_{\mathrm{M}}+R_{\mathrm{P}}, \\
& C_{\mathrm{T}}^{\mathrm{A} 254} \times R_{\mathrm{T}}=C_{\mathrm{O}}^{\mathrm{A} 254} \times R_{\mathrm{O}}+C_{\mathrm{M}}^{\mathrm{A} 254} \times R_{\mathrm{M}} \\
& \quad+C_{\mathrm{P}}^{\mathrm{A} 254} \times R_{\mathrm{P}}, \\
& C_{\mathrm{T}}^{\mathrm{EC}} \times R_{\mathrm{T}}=C_{\mathrm{O}}^{\mathrm{EC}} \times R_{\mathrm{O}}+C_{\mathrm{M}}^{\mathrm{EC}} \times R_{\mathrm{M}}+C_{\mathrm{P}}^{\mathrm{EC}} \times R_{\mathrm{P}},
\end{aligned}
$$

where $R_{\mathrm{T}}$ is the measured catchment run-off, and $R_{\mathrm{O}}, R_{\mathrm{M}}$, and $R_{\mathrm{P}}$ are the fractional run-off contribution from organic soil porewater, mineral soil groundwater, and precipitationlike endmembers, respectively. $C_{\mathrm{T}}^{\mathrm{A} 254}$ and $C_{\mathrm{T}}^{\mathrm{EC}}$ are the measured $A_{254}$ and $\mathrm{EC}$ at catchment outlets, while $C_{\mathrm{O}}^{\mathrm{A} 254} / C_{\mathrm{O}}^{\mathrm{EC}}$, $C_{\mathrm{M}}^{\mathrm{A} 254} / C_{\mathrm{M}}^{\mathrm{EC}}$, and $C_{\mathrm{P}}^{\mathrm{A} 254} / C_{\mathrm{P}}^{\mathrm{EC}}$ denote $A_{254}$ and $\mathrm{EC}$, respectively, for each of the three endmembers. Uncertainties in endmember contributions to streamflow were assessed by solving Eqs. (1)-(3) using combinations of endmember $A_{254}$ and EC $95 \%$ CI that yielded minimum and maximum streamflow contributions.

\subsection{Peatland porewater sampling}

Peatland porewater was collected on three occasions during the study period (early June, late July, and early September) in order to assess impacts of wildfire on porewater chemistry and to characterize the organic soil porewater endmember. Porewater was collected from a large peatland complex which was accessible by foot from the road $\left(61.19^{\circ} \mathrm{N}\right.$, $\left.120.08^{\circ} \mathrm{W}\right)$. Parts of the peatland complex had been affected by the 2013 Notawohka fire. Porewater was collected from non-permafrost thermokarst bogs and permafrost peat plateaus - in both burned and unburned sections. At each site, we dug three pits down to the water table $(\sim 10 \mathrm{~cm}$ in the thermokarst bog and $\sim 50 \mathrm{~cm}$ on the peat plateaus) and let the water fill in and particulates settle before collecting water samples in the same way as stream water samples described above. Water was collected near the water table position as this porewater is most likely to be laterally mobile and thus most likely to contribute to downstream streamflow. EC was measured directly in the dug pits using a handheld EC meter after water collection. Peatland porewater was analysed for
UV-vis absorbance and concentrations of DOC, TDN, and TDP, as described above.

\subsection{Radiocarbon dating of DOC and forest-floor litter}

We sampled and analysed radiocarbon content of DOC from the catchment outlets and peatland porewater and of forestfloor litter in 2017 , i.e. during the year following the main study period. The SC hydrograph in 2017 was similar to 2016, with no major storm flow during the summer. We collected stream water from both the SC and NW outlets on three occasions in 2017: 9 May, 7 July, and 11 September. On each occasion, we collected three replicate $2 \mathrm{~L}$ samples which were filtered in the field through pre-baked $0.7 \mu \mathrm{m}$ filters $\left(475^{\circ} \mathrm{C}\right.$ for $\left.4 \mathrm{~h}\right)$ using a pre-baked glass filtration assembly $\left(500^{\circ} \mathrm{C}\right.$ for $\left.4 \mathrm{~h}\right)$. Peatland porewater samples for DOC radiocarbon analysis were collected once, in early September, at the same sites as porewater had been collected in 2016 . We dug pits down to the water table and then inserted 10 MacroRhizones with a $0.15 \mu \mathrm{m}$ pore size (Rhizosphere Research Products, Wageningen, the Netherlands) into the peat at the level of the water table in each pit for porewater extraction. Pre-combusted bottles $(0.5 \mathrm{~L})$ were filled at each pit and then stored dark and cool to avoid photochemical or microbial degradation of DOC. We also collected triplicate mixed, representative, forest-floor litter samples from upland mixedwood forest, thermokarst bogs, burned peat plateaus, and unburned peat plateaus. Approximately $20 \mathrm{~g}$ of litter was collected in each sample. Samples were dried and ground up in the lab. The radiocarbon signature of DOC was measured following extraction and purification at the A.E. Lalonde AMS Laboratory, Ottawa, Canada, using a 3MV tandem accelerator mass spectrometer (High Voltage Engineering) following established methodologies (Lang et al., 2016; Palstra and Meijer, 2014; Zhou et al., 2015, Crann et al., 2017) and is reported with an error estimate of $1 \sigma$. The fraction modern carbon (fM) relative to 1950 was calculated according to Reimer et al. (2004) from the ratio of the sample ${ }^{14} \mathrm{C} /{ }^{12} \mathrm{C}$ to ${ }^{14} \mathrm{C} /{ }^{12} \mathrm{C}$ of an oxalic acid II standard measured in the same data block. Both ${ }^{14} \mathrm{C} /{ }^{12} \mathrm{C}$ ratios were background corrected using the AMS-measured ${ }^{13} \mathrm{C} /{ }^{12} \mathrm{C}$ ratio.

\section{Results}

\subsection{Catchment run-off}

We estimated 84 and $92 \mathrm{~mm}$ in total run-off between 29 April and 9 September 2016, from the SC and NW catchments, respectively (Table 1). This indicated no detectable difference in total run-off from the two catchments, given the uncertainty in the rating curve at the NW outlet at high discharge. The seasonal hydrograph was dominated by the freshet, and we defined the period 29 April until 26 May as the spring period, since this marked the end of the freshet and any subsequent rise in run-off occurred in response to rain (Fig. 4). 
Peak spring run-off from the SC catchment occurred on 5 May $\left(4.8 \mathrm{~mm} \mathrm{~d}^{-1}\right)$ and on 8 May from the larger NW catchment $\left(4.7 \mathrm{~mm} \mathrm{~d}^{-1}\right)$. Total run-off during the spring period was 62 and $61 \mathrm{~mm}$ from the SC and NW catchments, respectively, representing $75 \%$ and $67 \%$ of the total study period run-off. Run-off during the summer period was characterized mainly by base flow conditions, interrupted by a few minor storm events (Fig. 4). The NW catchment sustained greater run-off during the summer period, with 21 and $31 \mathrm{~mm}$ run-off from the SC and NW catchments, respectively.

Precipitation and air temperature data were available from the Fort Simpson meteorological station, located $50 \mathrm{~km}$ northwest of the Scotty Creek catchment outlet (data available through the Government of Canada, Environment and Climate Change Canada: http://climate.weather.gc.ca/, last access: 16 August 2018). In 2016, mean air temperature between May and September was $16.0^{\circ} \mathrm{C}$, compared to the $1980-2010$ average of $14.0^{\circ} \mathrm{C}$. Precipitation as snow in the winter preceding the study, from October 2015 until May 2016, was $153 \mathrm{~mm}$ compared to the long-term average of $152 \mathrm{~mm}$, while precipitation as rain from May until September during the study in 2016 was $169 \mathrm{~mm}$ compared to the long-term average of $203 \mathrm{~mm}$. Reflecting the normal snow accumulation prior to the freshet and the drier and warmer climatic conditions throughout May to September, we found that spring run-off from the SC catchment in 2016 was similar to the 1995-2015 average (62 vs. $61 \mathrm{~mm}$ ), while summer run-off in 2016 was much lower than the long-term average (21 vs. $65 \mathrm{~mm}$ ). The period from the start of the spring freshet until the end of our monitoring (9 September) has over the long-term record accounted for $86 \%$ of the annual run-off at the SC outlet.

\subsection{Water chemistry at catchment outlets}

Stream water chemistry monitoring was initiated during the early stages of the spring freshet, prior to complete ice breakup as indicated by water temperatures near $0{ }^{\circ} \mathrm{C}$ during the first sampling occasions (Fig. 4a). Stream water temperatures were consistently $1.5^{\circ} \mathrm{C}$ colder at the SC than NW outlet (Fig. 4a). Electrical conductivity increased from spring through summer, with minor decreases during summer storm events (Fig. 4b). The SC outlet had consistently lower EC than the NW outlet during spring and until early July. Both SC and NW outlets exhibited a negative relationship between EC and run-off (linear regression after log-log transformation: $\mathrm{SC} R^{2}=0.90$, NW $R^{2}=0.79$ ), although $\mathrm{EC}$ was lower than expected from this relationship during the rising limb of the spring freshet (Fig. 5b).

Both DOC and TDN concentrations reached seasonal minima during or just prior to peak spring run-off and then generally increased throughout the remainder of the study period (Fig. 4c, h). Concentrations of both DOC and TDN were negatively correlated with run-off at both outlets (linear regression after $\log -\log$ transformation: $\mathrm{SC} R^{2}=0.71$,
NW $R^{2}=0.89$ ), but concentrations were lower during the rising limb of the spring freshet than expected from these general relationships (Fig. 5b-c). A strong correlation was found between DOC and TDN concentrations that was common for the two outlets (linear regression, $R^{2}=0.91$ ), and DOC / TDN mass ratios thus had a relatively low variability between 30 and 40 at both outlets. Concentrations of DOC and TDN were generally lower at the SC than NW outlet.

While $A_{254}$ followed a seasonal pattern similar to DOC concentrations, with lowest absorbance during spring followed by generally rising absorbance throughout summer, we found that the ratio between $A_{254}$ and DOC, i.e. SUVA, varied significantly between 2.4 and $4.3 \mathrm{~L} \mathrm{mg} \mathrm{C}^{-1} \mathrm{~m}^{-1}$. Both SC and NW outlets had the highest SUVA, i.e. the highest DOC aromaticity, during the rising limb of the spring freshet, followed by the lowest SUVA during early summer and then higher again during late summer base flow conditions (Figs. 4e, 5d). The SC outlet had higher SUVA than the NW outlet during spring, while NW had higher SUVA than SC during most of the summer. We found an inverse relationship between SUVA and $S_{275-295}$ at the NW outlet $\left(R^{2}=0.64, p<0.01\right)$, suggesting that DOC aromaticity and average molecular weight were positively correlated. The $S_{275-295}$ record from the NW outlet further emphasized the distinct, high-molecular-weight and high-aromaticity, DOC characteristics during the rising limb of the spring freshet (Fig. 5e).

Concentrations of TP and TDP were highly correlated $\left(R^{2}>0.95, p<0.01\right)$ and were highest during the rising limb of the spring freshet, then decreased throughout spring, and rose slightly during low-run-off conditions in late summer (Fig. 4g). As such, TP and TDP were not correlated with run-off (Fig. 5f) or with DOC and TDN concentrations. However, TP and TDP concentrations were inversely correlated with $S_{275-295}$ at the NW outlet $\left(R^{2}=0.98\right.$ and 0.97 , respectively, both $p<0.01$ ), suggesting an association between (i) high-molecular weight DOC and (ii) high TP and TDP during the rising limb of the spring freshet and during late summer base flow conditions.

\subsection{Seasonal catchment DOC and nutrient yields}

Cumulative DOC yield from the SC and NW catchments during the study period was 1.40 and $1.91 \mathrm{~g} \mathrm{C} \mathrm{m}^{-2}$, respectively (Table 1). The lower DOC yield from the SC catchment was due to lower flow-weighted DOC concentration during spring ( $14.7 \mathrm{vs.} 18.2 \mathrm{mg} \mathrm{C} \mathrm{L}^{-1}$ ) when run-off was similar and due to less run-off during summer $(21 \mathrm{vs.} 31 \mathrm{~mm}$ ) when concentrations were similar. The spring period dominated the DOC yield during the study period, with $58 \%$ and $65 \%$ of total DOC yield during spring from SC and NW, respectively. The rising limb of the spring freshet, which had distinct DOC characteristics with regards to SUVA and $S_{275-295}$, was responsible for $27 \%$ and $26 \%$ of the total DOC yield from SC and NW, respectively. The yield of TDN, at 40 and 
Table 1. Cumulative run-off and solute yield from Scotty Creek and Notawohka Creek catchments during the 2016 study period.

\begin{tabular}{|c|c|c|}
\hline & Scotty Creek catchment & Notawohka Creek catchment \\
\hline Cumulative run-off & $84 \mathrm{~mm}$ & $92 \mathrm{~mm}$ \\
\hline Spring run-off ${ }^{1}$ & $62 \mathrm{~mm}(75 \%)$ & $61 \mathrm{~mm}(67 \%)$ \\
\hline Summer run-off ${ }^{2}$ & $21 \mathrm{~mm}(25 \%)$ & $31 \mathrm{~mm}(33 \%)$ \\
\hline Cumulative DOC yield & $1.40 \mathrm{~g} \mathrm{C} \mathrm{m}^{-2}$ & $1.91 \mathrm{~g} \mathrm{C} \mathrm{m}^{-2}$ \\
\hline Spring DOC yield & $0.91 \mathrm{~g} \mathrm{C} \mathrm{m}^{-2}(65 \%)$ & $1.11 \mathrm{~g} \mathrm{C} \mathrm{m}^{-2}(58 \%)$ \\
\hline Summer DOC yield & $0.49 \mathrm{~g} \mathrm{C} \mathrm{m}^{-2}(35 \%)$ & $0.79 \mathrm{~g} \mathrm{C} \mathrm{m}^{-2}(42 \%)$ \\
\hline Cumulative TDN yield & $40 \mathrm{mg} \mathrm{N} \mathrm{m}^{-2}$ & $51 \mathrm{mg} \mathrm{N} \mathrm{m}^{-2}$ \\
\hline Spring TDN yield & $28 \mathrm{mg} \mathrm{N} \mathrm{m}^{-2}(69 \%)$ & $30 \mathrm{mg} \mathrm{N} \mathrm{m}^{-2}(58 \%)$ \\
\hline Summer TDN yield & $13 \mathrm{mg} \mathrm{N} \mathrm{m}^{-2}(31 \%)$ & $22 \mathrm{mg} \mathrm{N} \mathrm{m}^{-2}(42 \%)$ \\
\hline Cumulative TP yield & $1.17 \mathrm{mg} \mathrm{P} \mathrm{m}^{-2}$ & $1.98 \mathrm{mg} \mathrm{P} \mathrm{m}^{-2}$ \\
\hline Spring TP yield & $1.03 \mathrm{mg} \mathrm{P} \mathrm{m}^{-2}(89 \%)$ & $1.57 \mathrm{mg} \mathrm{P} \mathrm{m}^{-2}(79 \%)$ \\
\hline Summer TP yield & $0.13 \mathrm{mg} \mathrm{P} \mathrm{m}^{-2}(11 \%)$ & $0.79 \mathrm{mg} \mathrm{P} \mathrm{m}^{-2}(21 \%)$ \\
\hline Cumulative TDP yield & $0.45 \mathrm{mg} \mathrm{P} \mathrm{m}^{-2}$ & $0.98 \mathrm{mg} \mathrm{P} \mathrm{m}^{-2}$ \\
\hline Spring TDP yield & $0.39 \mathrm{mg} \mathrm{P} \mathrm{m}^{-2}(86 \%)$ & $0.85 \mathrm{mg} \mathrm{P} \mathrm{m}^{-2}(87 \%)$ \\
\hline Summer TDP yield & $0.06 \mathrm{mg} \mathrm{P} \mathrm{m}^{-2}(14 \%)$ & $0.13 \mathrm{mg} \mathrm{P} \mathrm{m}^{-2}(13 \%)$ \\
\hline
\end{tabular}

129 April to 26 May. ${ }^{2} 27$ May to 9 September.

$51 \mathrm{mg} \mathrm{N} \mathrm{m}^{-2}$, respectively, from SC and NW, was proportional to the DOC yield throughout the study period with DOC/TDN mass ratios of 35 and 37 from SC and NW, respectively. The yield of TP was lower from the SC than NW catchment, at 1.17 and $1.98 \mathrm{mg} \mathrm{P} \mathrm{m}^{-2}$, respectively, mainly due to a flow-weighted TP concentration that was lower at the SC than NW outlet, at 0.014 and $0.022 \mathrm{mg} \mathrm{PL}^{-1}$. The DOC / TP yield mass ratio was overall greater at the SC than NW outlets, at 1200 and 960, respectively. The TP yields were even more dominated by the spring period than the DOC and TDN yield, with $79 \%$ and $89 \%$ of the total TP yield from SC and NW catchments occurring during the spring period and $>50 \%$ of the total TP yield occurring during the rising limb of the spring freshet at both catchment outlets.

\subsection{Streamflow contribution from different water sources}

Both catchments exhibited similar seasonal shifts in EC and $A_{254}$, which stayed within the mixing-space of the three identified potential endmembers: precipitation-like water, mineral soil groundwater, and organic soil porewater (Fig. 6a, b). The endmember mixing model indicated that streamflow was dominated by precipitation-like water during the spring period, with a shift towards mineral soil groundwater during summer. The continued contribution of precipitation-like water outside the freshet and storm events may indicate release of stored precipitation-like water in lakes and wetlands. The organic soil porewater contribution showed the least variability in the three endmembers over the season, contributing
$15 \%-20 \%$ of streamflow during spring and $20 \%-30 \%$ of streamflow during summer.

\subsection{Peatland porewater chemistry}

Wildfire was found to increase porewater TDP concentrations on the peat plateau and to increase the aromaticity of the DOC (higher SUVA), but was not found to influence concentrations of DOC or TDN (Fig. 7). Thermokarst bogs, which are unaffected by wildfire, had porewater characteristics similar to the unburned peat plateau, with the exception of lower TDN concentrations. From May until September across the three sampling occasions, there was a general trend of increasing $A_{254}$ (from 1.8 to $4.0 \mathrm{~m}^{-1}$, on average across all sites), DOC (from 52 to $100 \mathrm{mg} \mathrm{C} \mathrm{L}^{-1}$ ), TDN (from 1.2 to $1.8 \mathrm{mg} \mathrm{N} \mathrm{L}^{-1}$ ), and SUVA (from 3.5 to $4.0 \mathrm{~L} \mathrm{mg} \mathrm{C}^{-1} \mathrm{~m}^{-1}$ ). Concentrations of TDP were stable during the study period at the unburned peat plateau and thermokarst bog but decreased at the burned peat plateau (from 0.61 to $0.24 \mathrm{mg} \mathrm{P} \mathrm{L}^{-1}$ ).

\subsection{Radiocarbon dating}

Peat plateau porewater had significantly aged DOC, but showed no effect of wildfire, as both burned and unburned peat plateau DOC had an average fM of 0.80 (Fig. 8). In contrast, thermokarst bog porewater had only a minor aged DOC component at fM 0.98. Forest-floor litter from upland mixed-wood forests, thermokarst bogs, and peat plateaus were strongly influenced by ${ }^{14} \mathrm{C}$ bomb-enriched DOC with an average $\mathrm{fM}$ of 1.07. Stream water DOC at the SC and NW outlets varied between 1.05 and 0.99 , with the SC hav- 

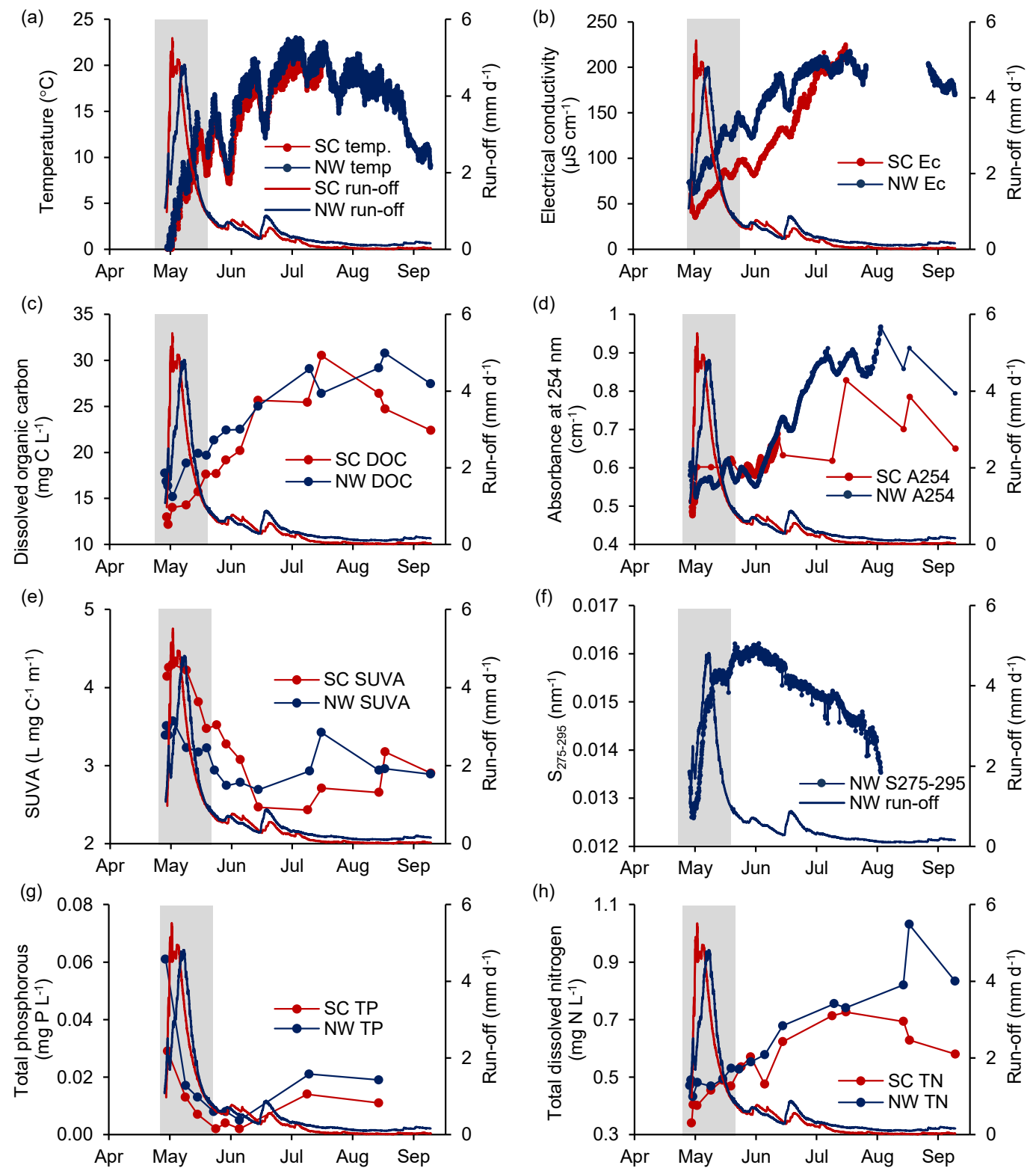

Figure 4. Seasonal variation in catchment run-off and stream water chemistry measured at the outlets of Scotty Creek catchment and the recently burned Notawohka Creek catchment, NT, Canada. Showing (a) temperature $\left({ }^{\circ} \mathrm{C}\right)$, (b) electrical conductivity $\left(\mu \mathrm{S} \mathrm{cm}{ }^{-1}\right),(\mathbf{c}) \mathrm{DOC}$ concentration $\left(\mathrm{mg} \mathrm{CL}^{-1}\right)$, (d) $A_{254 \mathrm{~nm}}\left(\mathrm{~cm}^{-1}\right)$, (e) SUVA $\left(\mathrm{L} \mathrm{mg} \mathrm{C}-1 \mathrm{~m}^{-1}\right)$, (f) $S_{275-295}$, (g) total phosphorous (mg PL $\left.{ }^{-1}\right)$, and (h) total dissolved nitrogen $\left(\mathrm{mg} \mathrm{N} \mathrm{L}^{-1}\right)$. The shaded grey area indicates the spring period (29 April-26 May).

ing higher values at each of the three sampling occasions particularly in July (Fig. 8).

\section{Discussion}

This study found overall similar seasonal patterns in DOC and nutrient yield from a recently burned ( 3 years prior) and an unburned catchment on the peatland-rich Taiga Plains in the discontinuous permafrost zone of western Canada. A few differences between the two catchments were consis- tent with impacts of fire on peatland porewater characteristics. Below we emphasize key results from this study that help us understand the controls on stream chemistry during transitions from periods of high to low run-off, the importance of the spring freshet for the annual solute yield, the impacts of wildfire on solute yield, and the potential for climate change to affect the magnitude of catchment DOC and nutrient yields from peatland-rich catchments in a region where similar studies are lacking. 

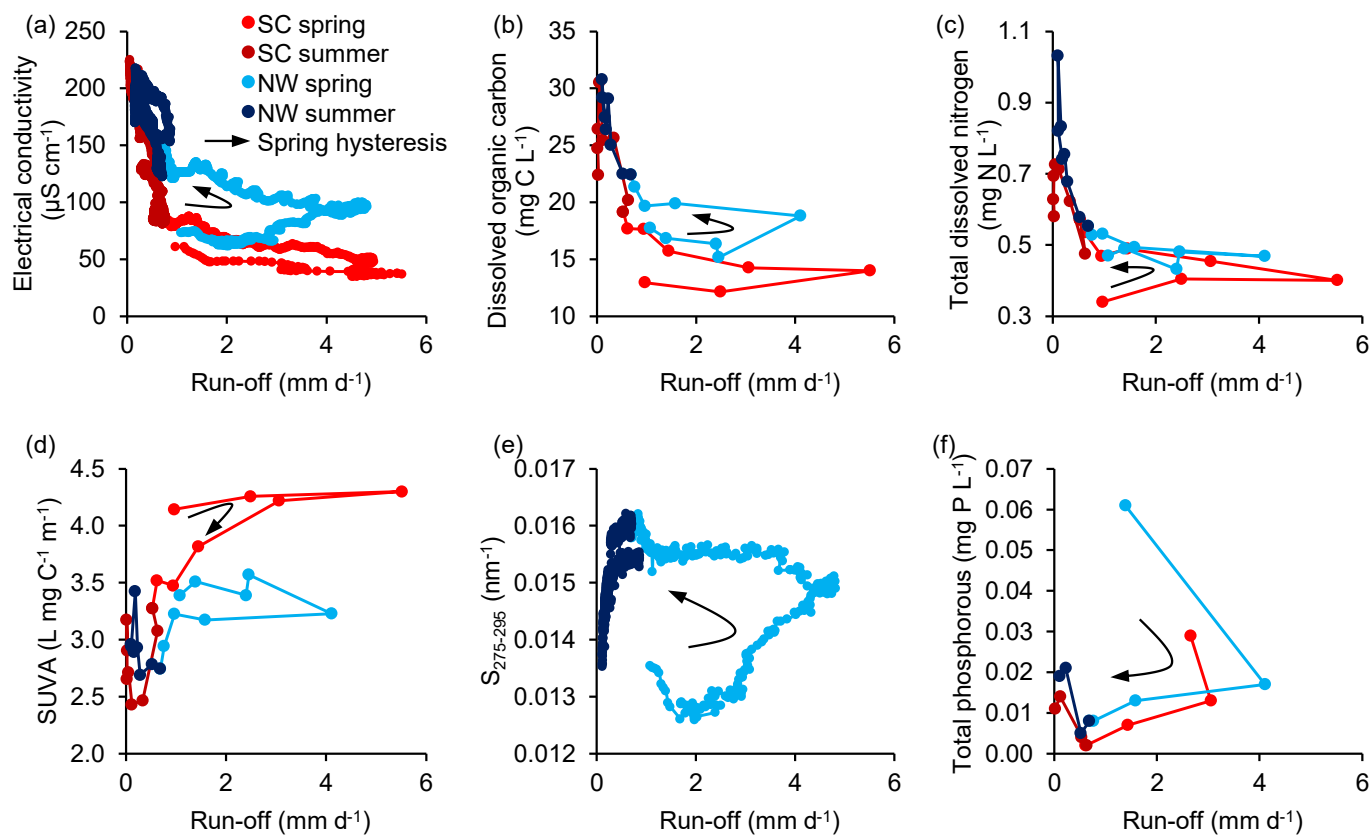

Figure 5. Relationships between run-off and (a) electrical conductivity, (b) DOC concentration, (c) total nitrogen, (d) SUVA, (e) $S_{275-295}$, and (f) total phosphorous at Scotty Creek (SC) and Notawohka Creek (NW) outlets in 2016. Spring (29 April-26 May) and summer periods (27 May-9 September) are indicated, and direction of hysteresis during spring is shown by arrows.
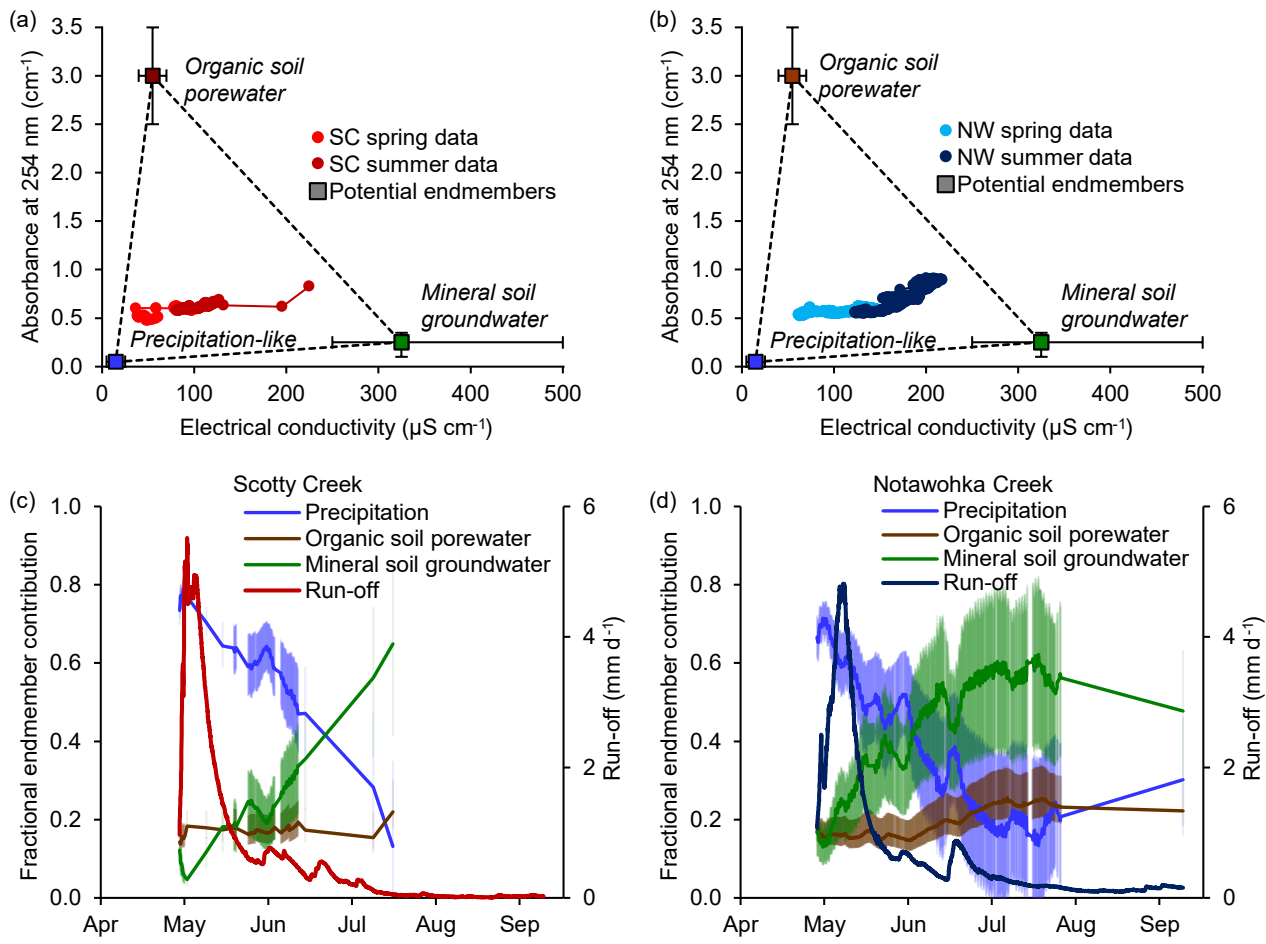

Figure 6. Endmember mixing space defined by decadal absorbance at $254 \mathrm{~nm}$ and electrical conductivity with outlet stream data from (a) Scotty Creek and (b) Notawohka Creek, as well as the fractional contribution to streamflow from potential endmembers at (c) Scotty Creek and (d) Notawohka Creek catchment outlets. Error bars in (a, b) indicate the $95 \%$ CI of the endmember characteristics (see Sect. 2 for justification), while error bars in (c) and (d) indicate the $95 \%$ CI for fractional endmember contribution to streamflow based on Eqs. (1)-(3) and the uncertainty in the endmember characterization. 

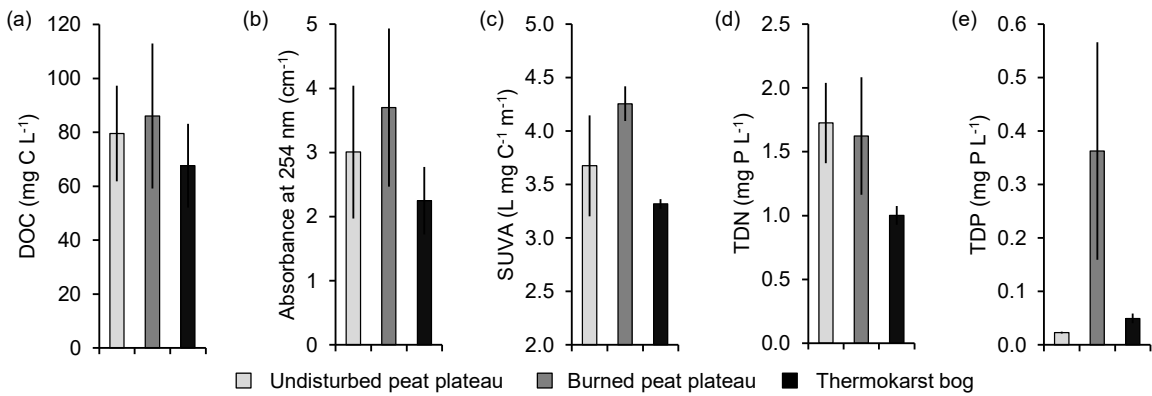

Figure 7. Porewater characteristics at undisturbed peat plateaus, recently burned peat plateaus, and thermokarst bogs; (a) dissolved organic carbon (DOC), (b) decadal absorbance at $254 \mathrm{~nm}$, (c) specific UV absorbance at $254 \mathrm{~nm}$ (SUVA), (d) total dissolved nitrogen (TDN), and (e) total dissolved phosphorous (TDP). Error bars indicate 1 SD based on three samples collected in early June, late July, and early September. The partially burned peatland site with both undisturbed and burned peat plateaus is located just outside the Notawohka catchment.

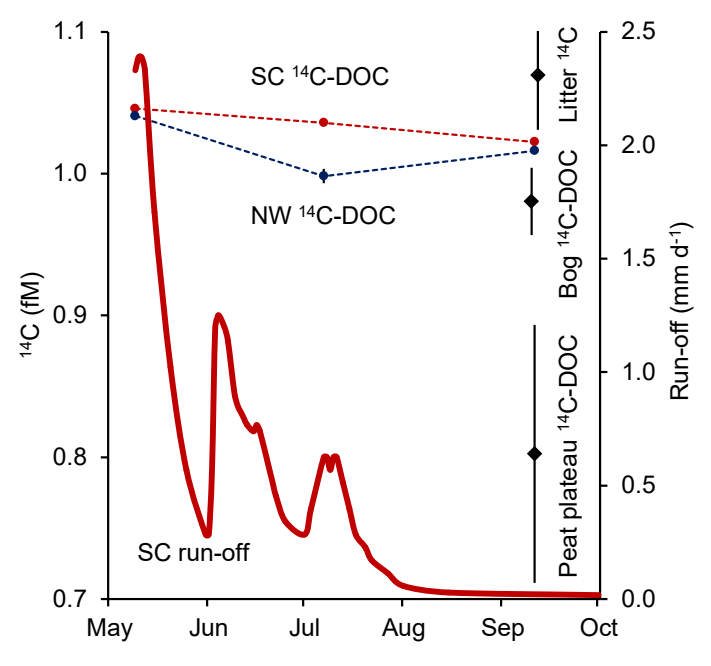

Figure 8. Radiocarbon characteristics of DOC at the Scotty Creek (SC) and Notawohka Creek (NW) outflows, of DOC in peat plateau (burned and unburned) and thermokarst bog pore water and of forest-floor litter. The Scotty Creek hydrograph for 2017 is shown. Error bars indicate $1 \mathrm{SD}$ among replicate samples. Error bars for stream DOC are all $<0.005$ and thus hard to see.

\subsection{Shifts in stream water chemistry as related to water sources}

Seasonal shifts in water chemistry and DOC characteristics at catchment outlets are common, but patterns vary strongly among catchments (Fellman et al., 2009; Larouche et al., 2015; Vonk et al., 2015; Broder et al., 2017). We found that the variability in water chemistry and DOC characteristics in this study was largely consistent with a model for run-off generation and solute yield from peatlands and upland forests based on data from boreal northern Europe, despite distinct differences in surficial geology and permafrost conditions (Laudon et al., 2011, Winterdahl et al., 2011). In this model, rising peatland run-off due to snowmelt and rain cause dilution of both DOC and TDN concentrations, while increas- ing run-off from upland forests shifts dominant riparian flow paths from deeper mineral soils to shallow organic soils and thus leads to decreasing concentrations of most dissolved ions but increasing DOC and TDN concentrations (Fig. 9a). These patterns of shifting water chemistry in run-off from peatland and upland forests can be conceptualized to result from mixing of the three endmembers used in our analysis (Fig. 9b). In run-off from peatlands, organic soil porewater would be expected to dominate under low-flow periods and to have an increasing contribution from precipitation-like water under high-flow periods. Run-off from upland forests would be expected to be dominated by mineral soil groundwater during low-flow periods, with the contribution from both organic soil pore water and precipitation-like water expected to increase under high-flow periods. Overall, water chemistry at catchment outlets is thus expected to be a function of run-off conditions and the relative abundance of wetland and upland forests within the catchment.

We accordingly found that DOC and TDN concentrations increased as run-off decreased after the spring period, which is consistent with peatlands dominating DOC and TDN yield from boreal catchments with $>60 \%$ peatlands cover and the dilution from precipitation-like water during high-flow periods (Laudon et al., 2011). The strong link between catchment DOC and TDN yield is common for boreal catchments (Kortelainen et al., 2006). The concurrent increase in EC after the spring period was, however, likely unrelated to shifting characteristics of peatland run-off, but rather linked to the parallel increase in the relative contribution from mineral soil groundwater sources to streamflow. The continued contribution from precipitation-like water well into the summer may be related to the slow release of snowmelt from storage in peatlands and lakes, as indicated by previous isotopic separation techniques for Scotty Creek (Hayashi et al., 2004).

The mixing between precipitation-like water, organic soil porewater, and mineral soil groundwater can also explain the seasonal variation in DOC aromaticity as indicated by SUVA. The aromaticity of DOC with high concentrations 

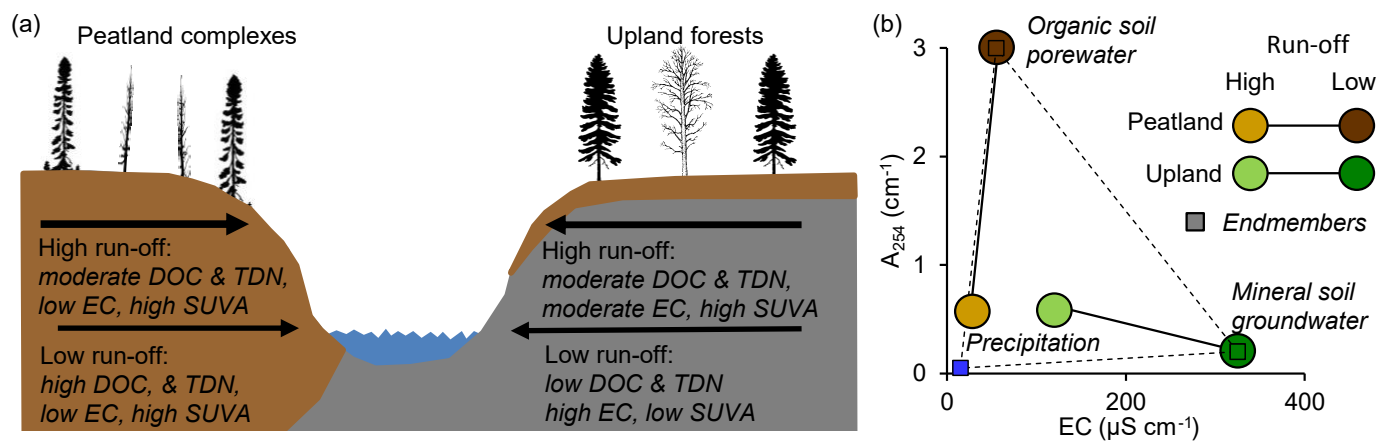

(c)

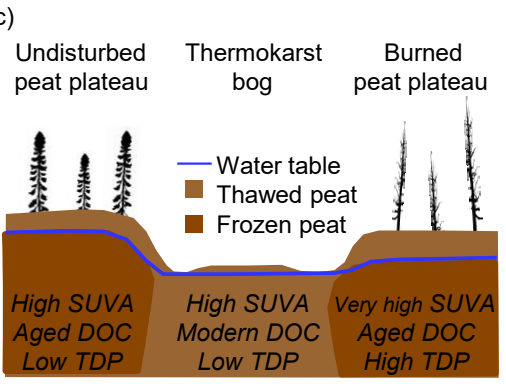

(d) Unburned
peat plateau Thermokarst bog Burned
peat plateau
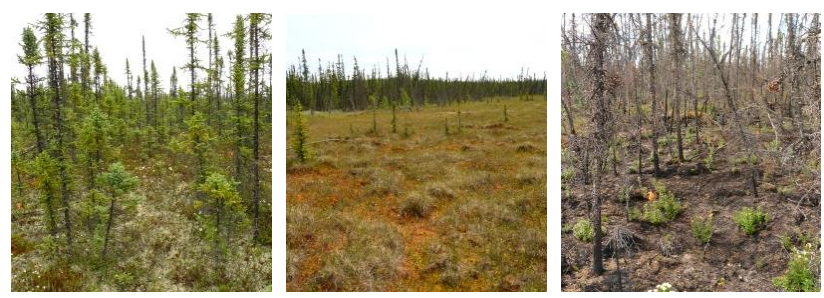

Figure 9. Conceptual controls on seasonal variation in stream chemistry for heterogeneous catchments with mixed peatland and upland forest land cover on the Taiga Plains of western Canada. (a) General water characteristics of run-off from peatlands and upland forests during lowand high-run-off generation, respectively. (b) Water chemistry of peatland and upland forest run-off during high and low-run-off periods, as conceptualized as a mixing of three endmembers: organic soil porewater, precipitation-like water, and mineral soil groundwater. Dotted line indicates the mixing space of endmembers. (c) Differences in DOC and nutrient characteristics among thermokarst bogs, undisturbed peat plateaus, and burned peat plateaus. (d) Representative photos of the three peatland types.

in peatland porewater in this study was similar to other studies with SUVA in the range 3.0 to $4.0 \mathrm{~L} \mathrm{mg} \mathrm{C}^{-1} \mathrm{~m}^{-1}$ (Tfaily et al., 2013; O'Donnell et al., 2016). This contrasts to the SUVA of low-concentration, microbially derived DOC found in mineral soil groundwater, which is often $<1.0 \mathrm{~L} \mathrm{mg} \mathrm{C}^{-1} \mathrm{~m}^{-1}$ (Olefeldt et al., 2013a; Shen et al., 2015). Stream water DOC thus had SUVA similar to peatland porewater during the spring period, albeit diluted by snowmelt, while stream DOC during summer had SUVA between 2.5 and $3.0 \mathrm{~L} \mathrm{mg} \mathrm{C}^{-1} \mathrm{~m}^{-1}$, which indicates a minor contribution also from mineral soil groundwater DOC. Despite low aromaticity, microbially derived DOC in mineral soil groundwater has been found to have low microbial lability (Olefeldt et al., 2013a) and thus the shift in stream water DOC characteristics from spring to summer likely indicate reduced microbial lability (Wickland et al., 2012). Although the mixing model helps explain much of the seasonal variability in EC, TDN, DOC, and DOC characteristics, patterns in TDP concentrations did not follow shifts in the relative contribution of the three identified endmembers - particularly during the rising limb of the spring freshet.

\subsection{Importance of spring for catchment solute yield}

This study emphasizes the need to characterize solute yield accurately during spring when studying northern catchments and during early spring in particular despite practical challenges (Holmes et al., 2012). Catchment run-off from both catchments during the study period in 2016 was evenly distributed between the rising limb of the spring freshet (lasting $\sim 10$ days), falling limb of the spring freshet ( $\sim 18$ days), and the summer period ( $\sim 105$ days). Similarly, $>25 \%$ of the catchment yield of DOC and TDN occurred during the rising limb of the freshet, and another $25 \%$ during the falling limb, while $>50 \%$ of the TP and TDP yields occurred during the rising limb of the spring freshet, with another $35 \%$ during the falling limb. Dominance of the spring freshet for the annual DOC and TDN yield is common for boreal and subarctic catchments (Finlay et al., 2006; Dyson et al., 2011; Olefeldt and Roulet, 2014), but the importance of TP yield during spring in this study was greater than observed elsewhere (Eimers et al., 2009).

The distinct stream chemistry during the rising limb of the spring freshet was likely associated with the contribution to streamflow from flow paths that are only hydrologically connected during this period, e.g. surficial flow paths forced by frozen ground (Ågren 2008). The rising limb of snowmelt was associated with the highest DOC aromaticity (highest SUVA) of the study period and the greatest DOC molecular weight (lowest $S_{275-295}$ ). Previous studies of Scandinavian catchments with significant wetland coverage found con- 
versely that the spring period had DOC with lower aromaticity than during the rest of the year ( $\AA$ gren et al 2008; Olefeldt and Roulet, 2014), while wetland catchments in Alaska had similar results as in this study (O'Donnell et al., 2010). The reason for these differences is not clear, but could possibly be due to ecosystem-specific DOC characteristics of nearsurface soil porewater. Several studies have found that DOC yielded during spring is of higher microbial lability than during summer (Mann et al., 2012; Wickland et al., 2012), which further emphasizes the importance of spring DOC yield for downstream biogeochemistry.

The rising limb of the freshet was also associated with the highest TP and TDP concentrations during the study period. Yields of TP and TDP from other boreal headwater catchments have been considered to be primarily organic $P$, as indicated by strong associations between (i) DOC and (ii) TP and TDP concentrations (Dillon and Molot, 1997; Eimers et al., 2009). In this study we had no correlation between (i) DOC and (ii) TP and TDP concentrations, and the highest TP and TDP concentrations in spring occurred when the streams were noticeably turbid. This finding suggested that spring export of inorganic P, e.g. in the form of phosphate bound to calcium or iron in colloidal particles (Reddy et al., 1999; Wang et al., 2005), was a major contributor to the annual catchment $P$ yield.

\subsection{Impacts of wildfire on catchment solute yield}

The greater TP and TDP yields from the burned Notawohka catchment than from the undisturbed Scotty Creek catchments were likely due to effects of fire. Fire leads to mineralization of organic $\mathrm{P}$, but not to gaseous combustion losses as for $\mathrm{C}$ and $\mathrm{N}$ (Neff et al., 2005), and this explains the observed higher TDP concentrations in porewater on the burned peat plateau compared to the unburned peat plateau. Increased catchment yield of TP or TDP following fire has previously been indicated for several other Canadian regions, including the non-permafrost Boreal Plains in western Canada (McEachern et al., 2000; Burke et al., 2005), the boreal shield of eastern Canada (Lamontagne et al., 2000), and in the foothills of the Rocky Mountains (Silins et al., 2014). This study suggests that the ratio between annual cumulative DOC and TP yield may be a sensitive indicator of the effects of wildfire when comparing across boreal catchments under different climates. In this study we found yield ratios of DOC to TP yield at 1200 and 950 for the undisturbed and burned catchments, respectively. This is consistent with other boreal catchments where the range has been 1200 to 2000 for undisturbed and $<1000$ for burned catchments (Dillon and Molot, 1997; Lamontagne et al., 2000; Kortelainen et al., 2006). Increased TP yield has been linked to increased stream algal production, suggesting much of the additional $\mathrm{P}$ loading is reactive, which in turn has cascading effects on high trophic levels, e.g. on invertebrate and fish populations (Silins et al., 2014). Qualitatively, we observed noticeably greater epiphytic algal growth in the stream channel of Notawohka Creek than Scotty Creek, suggesting that increased catchment $\mathrm{P}$ yield following fire in the study region may have important effects on aquatic productivity and food web structure.

The effect of wildfire on catchment yield of DOC has been inconsistent among studies of boreal catchments (Lamontagne et al., 2000; McEachern et al 2000; Petrone et al., 2007; Olefeldt et al 2013a; Parham et al., 2013). This suggests that climate or catchment characteristics are likely to modulate any effects of wildfire. In this study, we observed greater DOC yield from the burned Notawohka Creek catchment during summer, a period when DOC yield further was associated with higher DOC aromaticity and a greater contribution from aged DOC than from the undisturbed Scotty Creek catchment. While this could arise from many factors which this study cannot differentiate, this difference is consistent with increased run-off generation from burned peat plateaus during summer. Peat plateaus are slightly raised above the surrounding peatland and thus shed water throughout summer as the seasonally thawed layer deepens (Quinton et al., 2009). The seasonally thawed layer of peat plateaus in the study region increases from a maximum of $\sim 70$ to $\sim 120 \mathrm{~cm}$ during the first few years following fire due to altered surface energy balance (Gibson et al., 2018), which thus creates an increased potential for summer run-off generation. As the burned peat plateau had porewater with higher DOC aromaticity and higher TDP concentrations than the undisturbed peat plateau (Fig. 9c-d), increased summer run-off generation after fire would thus be expected to lead to the observed differences at the catchment outlets.

The increased contribution of aged DOC to catchment DOC yield during summer is also consistent with increased contribution of run-off from burned peat plateaus to catchment DOC export. Both the burned and unburned peat plateaus were found to have significantly aged porewater DOC (fM: $0.65-0.85: 3700-1250 \mathrm{cal} \mathrm{BP}$ ), while the non-permafrost bogs had much younger porewater DOC (fM: 0.95-1.00, 500-0 cal BP) (Fig. 9c). Several other boreal non-permafrost peatlands have similarly been found to have predominately modern porewater DOC, even at several metres depth where the peat itself is thousands of years old (Wilson et al., 2016; Campeau et al., 2017). An important difference between peat plateaus and boreal non-permafrost peatlands may be the greater depth of the aerobic surface layer in peat plateau systems (Fig. 9c) that could enhance DOC production from aged peat. In contrast, peat under anaerobic conditions in wetter non-permafrost bogs appears largely inert, and DOC at significant depth has been found to be modern ( $\mathrm{fM} \sim 1.0$ ) - likely leached from plants near the surface (Wilson et al., 2016; Campeau et al., 2017). Despite the aged DOC in peat plateau porewater, DOC at the catchment outlets was still found to be predominately modern (fM: 0.991.05). The sampling in July at the Notawohka Creek outlet was in fact the only occasion when the stream DOC sample 
was not dominated by modern $\mathrm{C}$ ( $\mathrm{fM}<1.00$ ). This suggests that while catchment DOC yields were mainly comprised of young or bomb-peak-influenced DOC, e.g. the thermokarst bog DOC porewater (fM: 0.95-1.00) or from DOC leachates from forest litter (fM: 1.05-1.10), there may have been an additional contribution from the burned peat plateaus in the NW catchment.

\subsection{Climatic controls on DOC and nutrient yield on the Taiga Plains}

The dry climate of the study region restricted the cumulative catchment DOC yield to $<2 \mathrm{~g} \mathrm{C} \mathrm{m}^{-2}$ for the study period, which is substantially lower than the range 4 to $15 \mathrm{~g} \mathrm{C} \mathrm{m}^{-2} \mathrm{yr}^{-1}$ found for boreal catchments in other regions with similar peatland coverage (Lamontagne et al., 2000; Olefeldt et al., 2013b). Run-off during the 2016 study period from the Scotty Creek catchment was $85 \mathrm{~mm}$, below the long-term (1995-2015) average of $125 \mathrm{~mm}$ for the same period. However, the long-term record also shows that the region has a very large inter-annual variability in run-off generation, with a range in annual run-off between 30 and $330 \mathrm{~mm}$. This large variability is likely a consequence of the balance between precipitation and evapotranspiration in this dry boreal climate, where even small variability in either precipitation or evapotranspiration causes relatively large variability in run-off. Climate change thus has a large potential to cause altered run-off patterns in the region through altered precipitation or evapotranspiration, which would also strongly influence catchment yields of DOC and nutrients.

Climate change may also influence catchment DOC and nutrient yield in the study region through permafrost thaw. Permafrost thaw in peatlands in this study region is associated with a transition of peat plateaus into thermokarst bogs and channel fens (Chasmer and Hopkinson, 2017; Gibson et al., 2018), a transition which alters both the porewater DOC characteristics (Gordon et al., 2016) and the landscape hydrological connectivity (Connon et al., 2015). Variability in mean annual run-off among catchments in this region has been linked to the relative abundance of channel fens (Quinton et al., 2011), and increasing run-off from Scotty Creek during the period 1997 to 2011 has been linked to ongoing loss of peat plateaus (Chasmer and Hopkinson, 2017). The transition from the Taiga Plains, where peatlands have discontinuous permafrost, to the Boreal Plains further south, where permafrost is absent, has been shown to correspond to significantly higher stream DOC concentrations when comparing catchments with similar wetland extents (Olefeldt et al., 2014). Continued permafrost thaw is thus expected to increase catchment DOC yield and alter its chemical characteristics (Wauthy et al., 2018). On the Taiga Plains this effect of climate change on catchment solute yield characteristics is further likely to be accelerated by wildfire, as wildfire is a dominant disturbance and has been found to significantly ac- celerate the rate of peat plateau loss due to permafrost thaw (Gibson et al., 2018).

\section{Conclusions}

In this study we have shown that monitoring during the traditionally understudied spring freshet, particularly the rising limb of the freshet, is required to accurately characterize catchment DOC and nutrient yield. In the study year, more than half of the cumulative TP yield occurred during the first week of the freshet, and more than half of the DOC and TN yield occurred during the 4 -week spring period. The burned catchment was found to have a significantly higher TDP yield than the undisturbed catchment, and this difference appeared linked to increased availability of TDP in porewater of burned ecosystems. Effects of wildfire on catchment DOC and TN yield were less clear, although increased DOC yield during summer, with greater aromaticity and greater contribution from aged $\mathrm{C}$, was consistent with increased run-off generation during summer from burned peat plateaus where the seasonally thawed soil layer is rapidly deepening during the first few years after fire. Further studies are, however, required to link wildfire definitively to these effects on DOC and TN yield in the study region. Our results suggest that the effects of wildfire on catchment DOC and TN yield are likely to be less important than expected changes anticipated from climate change, due to its effects on permafrost thaw and run-off generation.

Data availability. The data that support the findings of this study are available from the corresponding author upon reasonable request.

Author contributions. KB, DO, and SET conceived and designed the study. KB, DO, and ND collected data. AJT and SET facilitated the radiocarbon analysis. KB and DO carried out the data analysis. All authors aided in data interpretation and the writing of the manuscript.

Competing interests. The authors declare that they have no conflict of interest.

Special issue statement. This article is part of the special issue "Understanding and predicting Earth system and hydrological change in cold regions". It is not association with a conference.

Acknowledgements. This study was funded by support from the National Science and Engineering Research Council Discovery grant (RGPIN-2016-04688); the Campus Alberta Innovates Program; the University of Alberta Northern Research Awards; a UK-Canada Arctic Partnership Bursary, from the Department 
for Business, Energy and Industrial Strategy supported by the NERC Arctic Office; and the Polar Knowledge Canada (POLAR) Science and Technology program. We thank William Heffernan, Carolyn Gibson, Michael Barbeau, Jessi Steinke, Megan Schmidt, Cristian Estop-Aragones, and McKenzie Kuhn for their help with field work.

Edited by: Sean Carey

Reviewed by: two anonymous referees

\section{References}

Ågren, A., Berggren, M., Laudon, H., and Jansson, M.: Terrestrial export of highly bioavailable carbon from small boreal catchments in spring floods, Freshwater Biol., 53, 964-972, https://doi.org/10.1111/j.1365-2427.2008.01955.x, 2008.

Ågren, A. M., Buffam I., Cooper D. M., Tiwari T., Evans C. D., and Laudon H.: Can the heterogeneity in stream dissolved organic carbon be explained by contributing landscape elements?, J. Geophys. Res.-Biogeo., 11, 1199-1213, https://doi.org/10.5194/bg11-1199-2014, 2014.

Aylsworth, J. M., Burgess, M. M., Desrochers, D. T., Duk-Rodkin, A., Robertson, T., and Traynor, J. A.: Surficial geology, subsurface materials, and thaw sensitivity of sediments; in: The Physical Environment of the Mackenzie Valley, Northwest Territories: a Base Line for the Assessment of Environmental Change, edited by: Dyke, L. D. and Brooks, G. R., Geological Survey of Canada, Bulletin, 547, 41-48, 2000.

Betts, E. F. and Jones Jr., J. B.: Impact of Wildfire on Stream Nutrient Chemistry and Ecosystem Metabolism in Boreal Forest Catchments of Interior Alaska. Arct, Antarct Alpine Res., 41, 407-417, https://doi.org/10.1657//1938-4246-41.4.407, 2009

Braaten, H. F. V., de Wit, H. A., Fjeld, E., Rognerud, S., Lyndersen, E., and Larssen, T.: Environmental factors influencing mercury speciation in Subarctic and Boreal lakes, Sci. Tot. Environ., 476, 336-345, https://doi.org/10.1016/j.scitotenv.2014.01.030, 2014.

Broder, T., Knorr, K.-H., and Biester, H.: Changes in dissolved organic matter quality in a peatland and forest headwater stream as a function of seasonality and hydrologic conditions, Hydrol. Earth Syst. Sci., 21, 2035-2051, https://doi.org/10.5194/hess-212035-2017, 2017.

Burke, J. M., Prepas, E. E., and Pinder, S.: Runoff and phosphorus export patterns in large forested watersheds on the western Canadian Boreal Plain before and for 4 years after wildfire, J. Environ. Eng. Sci., 4, 319-325, https://doi.org/10.1139/s04-072, 2005.

Campeau, A., Bishop, K. H., Billet, M. F., Garnett, M. H., Laudon, H., Leach, J. A., Nillson, M. B., Öquist, M. G., and Wallin, M. B.: Aquatic export of young dissolved and gaseous carbon from a pristine boreal fen: Implications for peat carbon stock stability, Glob. Change Biol., 23, 5523-5536, https://doi.org/10.1111/gcb.13815, 2017.

Carey, S. K.: Dissolved organic carbon fluxes in a discontinuous permafrost subarctic alpine catchment, Permafrost Periglac., 14, 161-171, https://doi.org/10.1002/ppp.444, 2003.

Carignan, R., D'Arcy, P., and Lamontagne, S.: Comparative impacts of fire and forest harvesting on water quality in Boreal Shield lakes, Can. J. Fish Aquat. Sci., 57, 105-117, https://doi.org/10.1139/f00-125, 2000.
Chasmer, L. and Hopkinson, C.: Threshold loss of discontinuous permafrost and landscape evolution. Glob. Change Biol., 23, 2672-2686, https://doi.org/10.1111/gcb.13537, 2017.

Christopherson, N. and Hooper, R. P.: Multivariate analysis of stream water chemical data: the use of principal components analysis for the end member mixing problem, Water Resour Res., 28, 99-107, https://doi.org/10.1029/91WR02518, 1992.

Connon, R. F., Quinton, W. L., Craig, J. R., Hanisch, J., and Sonnentag, O.: The hydrology of interconnected bog complexes in discontinuous permafrost terrains, Hydrol. Proc., 29, 3831-3847, https://doi.org/10.1002/hyp.10604, 2015.

Cory, R. M. and Kaplan, L. A.: Biological lability of streamwater fluorescent dissolved organic matter, Limnol. Oceanogr., 57, 1347-1360, https://doi.org/10.4319/lo.2012.57.5.1347, 2012.

Crann, C. A., Murseli, S., St-Jean, G., Zhao, X., Clark, I. D., and Kieser, W. E.: First status report on radiocarbon sample preparation techniques at the A. E. Lalonde AMS Laboratory (Ottawa, Canada), Radiocarbon, 59, 695-704, https://doi.org/10.1017/RDC.2016.55, 2017.

Dillon, P. J. and Molot, L. A.: Effect of landscape form on export of dissolved organic carbon, iron, and phosphorus from forested stream catchments, Water Resour. Res., 33, 2591-2600, https://doi.org/10.1029/97WR01921, 1997.

Dyson, K. E., Billett, M. F., Dinsmore, K. J., Harvey, F., Thomson, A. M., Piirainen, S., and Kortelainen, P.: Release of aquatic carbon from two peatland catchments in E., Finland during the spring snowmelt period, Biogeochemistry, 103, 125-142, https://doi.org/10.1007/s10533-010-9452-3, 2011.

Ecosystem Classification Group: Ecological regions of the Northwest Territories - Taiga Plains, Department of Environment and Natural Resources, Government of the Northwest Territories, Yellowknife, NT, vii + 173 p. + folded insert map, 2007 (rev. 2009).

Eimers, M. C., Watmough, S. A., Paterson, A. M., Dillon, P. J., and Yao, H.: Long-term declines in phosphorus export from forested catchments in south-central Ontario, Can. J. Fish Aquat. Sci, 66, 1682-1692. https://doi.org/10.1139/F09-101, 2009.

Fellman, J. B., Hood, E., D'Amore, V. D., Edwards, R. T., and White, D.: Seasonal changes in the chemical quality and biodegradability of dissolved organic matter exported from soils to streams in coastal temperate rainforest watersheds, Biogeochemistry, 95, 277-293, https://doi.org/10.1007/s10533-0099336-6, 2009.

Fichot, C. G. and Benner, R.: The spectral slope coefficient of chromorphoric dissolved organic matter $\left(S_{275-295}\right)$ as a tracer of terrigenous dissolved organic carbon in riverinfluenced ocean margins, Limnol. Oceanogr., 57, 1453-1466, https://doi.org/10.4319/lo.2012.57.5.1453, 2012.

Finlay, J., Neff, J., Zimov, S., Davydova, A., and Davydov, S.: Snowmelt dominance of dissolved organic carbon in high-latitude watersheds: Implications for characterization and flux of river DOC, Geophys. Res. Lett., 33, L10401, https://doi.org/10.1029/2006GL025753, 2006.

Flannigan, M. D., Stocks, B. J., Turetsky, M. R., and Wotton, B. M.: Impacts of climate change on fire activity and fire management in the circumboreal forest, Glob. Change Biol., 15, 549560, https://doi.org/10.1111/j.1365-2486.2008.01600.x, 2009. 
Fraser, C., Roulet, J. D., and Lafleur, M.: Groundwater flow patterns in a large peatland, J. Hydrol., 246, 142-154, https://doi.org/10.1016/S0022-1694(01)00362-6, 2001.

Gibson, C. M., Chasmer, L. A., Thompson, D. K., Quinton, W. L., Flannigan, M. D., and Olefeldt, D.: Wildfire as a major driver of recent permafrost thaw in boreal peatlands, Nat. Comm., 9, 3041, https://doi.org/10.1038/s41467-018-05457-1, 2018.

Godsey, S., Kirchner, J. W., and Clow, D. W.: Concentrationdischarge relationships reflect chemostatic characteristics of US catchments, Hydrol. Proc., 23, 1844-1864, https://doi.org/10.1002/hyp.7315, 2009.

Gordon, J., Quinton, W., Branfireun, B., and Olefeldt, D.: Mercury and methylmercury biogeochemistry in a thawing permafrost wetland complex, Northwest Territories, Canada, Hydrol. Proc., 30, 3627-3638, https://doi.org/10.1002/hyp.10911, 2016.

Hayashi, M., Quinton, W. L., Pietroniro, A., and Gibson, J. J.: Hydrologic functions of wetlands in a discontinuous permafrost basin indicated by isotopic and chemical signatures, J. Hydrol., 296, 81-97, https://doi.org/10.1016/j.jhydrol.2004.03.020, 2004.

Helms, J. R., Stubbins, A., Ritchie, J. D., Minor, E. C., Kieber, D. J., and Mopper, K.: Absorption spectral slopes and slope rations as indicators of molecular weight, source, and photobleaching of chromophoric dissolved organic matter, Limnol. Oceanogr., 53, 955-969, https://doi.org/10.4319/lo.2008.53.3.0955, 2008

Holmes, R. M., McClelland, J. W., Peterson, B. J., Tank, S. E., Bulygina, E., Eglinton, T. I., Gordeev, V. V., Gurtovaya, T. Y., Raymond, P. A., Repeta, D. J., Staples, R., Striegl, R. G., Zhulidov, A. V., and Zimov, S. A.: Seasonal and annual fluxes of nutrients and organic matter from large rivers to the Arctic Ocean and surrounding seas, Estuar. Coast., 35, 369-382, https://doi.org/10.1007/s12237-011-9386-6, 2012.

Hugelius, G., Routh, J., Kuhry, P., and Cril, P.: Mapping the degree of decomposition and thaw remobilization potential of soil organic matter in discontinuous permafrost terrain, J. Geophys. Res., 1117, G02030, https://doi.org/10.1029/2011JG001873, 2012.

Jantze, E. J.,Laudon, H., Dahlke, H. E., and Lyon, S. W.: Spatial variability of dissolved organic and inorganic carbon in subarctic headwater streams, Arct. Antarct. Alp. Res., 47, 529-546, https://doi.org/10.1657/AAAR0014-044, 2015.

Lamontagne, S., Carignan, R., D’Arcy, P., and Prairie, Y. T.: Element export in runoff from eastern Canadian Boreal Shield drainage basins following forest harvesting and wildfires, Can. J. Fish. Aquat. Sci., 57, 118-128, https://doi.org/10.1139/f00-108, 2000.

Larouche, J. R., Abbott, B. W., Bowden, W. B., and Jones, J. B.: The role of watershed characteristics, permafrost thaw, and wildfire on dissolved organic carbon biodegradability and water chemistry in Arctic headwater streams, J. Geophys. Res.-Biogeo., 12, 4221-4233, https://doi.org/10.5194/bg-12-4221-2015, 2015.

Laudon, H., Berggren, M., Ågren, A., Buffam, I., Bishop, K., Grabs, T., Jansson, M., and Köhler, S.: Patterns and dynamics of dissolved organic carbon (DOC) in boreal streams: The role of processes, connectivity, and scaling, Ecosystems, 14, 800-893, https://doi.org/10.1007/s10021-011-9452-8, 2011.

Ledesma, J. L. J, Futter, M. N., Blackburn, M., Lidman, F., Grabs, T., Sponseller, R. A., Laudon, H., Bishop, K. H., and Köhler, S. J.: Towards an improved conceptualization of riparian zones in boreal forest headwaters, Ecosystems, 21, 297-315, https://doi.org/10.1007/s10021-017-0149-5, 2017.

Kaiser, K. and Kalbitz, K.: Cycling downwards - dissolved organic matter in soils, Soil Biol. Biochem., 52, 29-32, https://doi.org/10.1016/j.soilbio.2012.04.002, 2012.

Karlsson, J., Biström, P., Ask, J., Ask, P., Persson, L., and Jansson, M.: Light limitation of nutrient-poor lake ecosystems, Nature, 460, 506-509, https://doi.org/10.1038/nature08179, 2009.

Kortelainen, P., Mattson, T., Finer, L., Ahtiainen, M., Saukkonen, S., and Sallantaus, T.: Controls on the export of C, N, P and Fe from undisturbed boreal catchments, Finland, Aquat. Sci., 4, 453-468, https://doi.org/10.1007/s00027-006-0833-6, 2006.

Kothawala, D. N., Ji, X., Laudon, H., Ågren, A. M., Futter, N. M., Köhler, S. J., and Tranvik, L. J.: The relative influence of land cover, hydrology, and in-stream processing on the composition of dissolved organic matter in boreal streams, J. Geophys. Res.-Biogeo., 120, 1491-1505, https://doi.org/10.1002/2015JG002946, 2015.

Lang, S. Q., McIntyre, C. P., Bernasconi, S. M., Früh-Green, G. L., Voss, B. M., Eglinton, T. I., and Wacker, L.: Rapid ${ }^{14} \mathrm{C}$ analysis of dissolved organic carbon in non-saline waters, Radiocarbon, 58, 505-515, https://doi.org/10.1017/RDC.2016.17, 2016.

Mann, P. J., Davydova, A., Zimov, N., Spencer, R. G. M., Davydov, S., Bulygina, E., Zimov, S., and Holmes, R. M.: Controls on the composition and lability of dissolved organic matter in Siberia's Kolyma River basin, J. Geophys. Res.-Biogeo., 117, G01028, https://doi.org/10.1029/2011JG001798, 2012.

Mann, P. J., Davydova, A., Zimov, N., Spencer, R. G. M., Davydov, S., Vulygin, E., Zimov, S., and Holmes, R. M.: Controls on the composition and lability of dissolved organic matter in Siberia's Kolyma River basin, J. Geophys. Res., 117, G01028, https://doi.org/10.1029/2011JG001798, 2012.

Marchand, D., Prairie, Y. T., and del Giorgio, P. A.: Linking forest fires to lake metabolism and carbon dioxide emissions in the boreal region of Northern Québec, Glob. Change Biol., 15, 28612873, https://doi.org/10.1111/j.1365-2486-2009.01979.x, 2009.

McEachern, P. Prepas, E. E., Gibson, J. J., and Dinsmore, W. P.: Forest fire induced impacts on phosphorus, nitrogen, and chlorophyll a concentrations in boreal subarctic lakes of northern Alberta, Can. J. Fish. Aquat. Sci., 57, 73-81, https://doi.org/10.1139/f00124, 2000.

Neff, J. C., Harden, J. W., and Gleixner, G.: Fire effects on soil organic matter content, composition, and nutrients in boreal interior Alaska, Can. J. Forest Res., 35, 2178-2187, https://doi.org/10.1139/x05-154, 2005.

Northwest Territories Fire Scar Map: Centre for Geomatics, Government of the Northwest Territories, available at: www. geomatics.gov.nt.ca (last access: 16 August 2018), 2013.

Obernosterer, I. and Benner, R.: Competition between biological and photochemical processes in the mineralization of dissolved organic carbon, Limnol. Oceanogr., 49, 117-124, https://doi.org/10.4319/lo.2004.49.1.0117, 2004.

O'Donnell, J. A., Aiken, G. R., Kane, E. S., and Jones, J. B.: Source water controls on the character and origin of dissolved organic matter in streams of the Yukon River basin, Alaska, J. Geophys. Res.-Biogeo., 115, G03025 https://doi.org/10.1029/2008JG001153, 2010.

O’Donnell, J. A., Aiken, G. R., Butler, K. D., Guillemette, F., Podgorski, D. C., and Spencer, R. G. M.: DOM com- 
position and transformation in boreal forest soils: The effects of temperature and organic-horizon decomposition state, J. Geophys. Res.-Biogeo., 121, 2727-2744, https://doi.org/10.1002/2016JG003431, 2016.

Olefeldt, D. and Roulet, N. T.: Permafrost conditions in peatlands regulate magnitude, timing, and chemical composition of catchment dissolved organic carbon export, Glob. Change Biol., https://doi.org/10.1111/gcb.12607, 2014.

Olefeldt, D., Devito, K. J., and Turetsky, M. R.: Sources and fate of terrestrial dissolved organic carbon in a Boreal Plains region recently affected by wildfire, J. Geophys. Res.-Biogeo., 10, 62476265, https://doi.org/10.5194/bg-10-6247-2013, 2013a.

Olefeldt, D., Roulet, N., Giesler, R., and Persson, A.: Total waterborne carbon export and DOC composition from ten nested subarctic peatland catchments - importance of peatland cover, groundwater influence, and inter-annual variability of precipitation patterns, Hydrol. Proc., 27, 2280-2294, https://doi.org/10.1002/hyp.9358, 2013b.

Olefeldt, D., Turetsky, M. R., and Blodau, C.: Altered composition and microbial versus UV-mediated degradation of dissolved organic matter in boreal soils following wildfire, Ecosystems, 16, 1396-1412, https://doi.org/10.1007/s10021-013-9691-y, 2013c.

Olefeldt, D., Persson, A., and Turetsky, M. R.: Influence of the permafrost boundary on dissolved organic matter characteristics in rivers within the Boreal and Taiga plains of western Canada, Environ. Res. Lett., 9, 035005, https://doi.org/10.1088/17489326/9/3/035005, 2014.

Palstra, S. and Meijer, H.: Biogenic carbon fraction of biogas and natural gas fuel mixtures determined with ${ }^{14} \mathrm{C}$, Radiocarbon, 56, 7-28, https://doi.org/10.2458/56.16514, 2014.

Parham, L. M., Prokushkin, A. S., Pokrovsky, O. S., Titov, S. V., Grekova, E., Shirokova, L. S., and McDowell, W. H.: Permafrost and fire as regulators of stream chemistry in basins of the Central Siberian Plateau, Biogeochemistry, 116, 55-68, https://doi.org/10.1007/s10533-013-9922-5, 2013.

Petrone, K. C., Hinzman, L. D., Shibata, H., Jones, J. B., and Boone, R. D.: The influence of fire and permafrost on sub-arctic stream chemistry during storms, Hydrol. Proc., 21, 423-434, https://doi.org/10.1002/hyp.6247, 2007.

Quinton, W. L., Hayashi, M., and Chasmer, L. E.: Peatland hydrology of discontinuous permafrost in the Northwest Territories: Overview and synthesis, Can. Water Resour. J., 34, 311-328, https://doi.org/10.4296/cwrj3404311, 2009.

Quinton, W. L., Hayashi, M., and Chasmer, L .E.: Permafrostthaw-induced land-cover change in the Canadian subarctic: implications for water resources, Hydrol. Proc., 25, 152-158, https://doi.org/10.1002/hyp.7894, 2011.

Raymond, P. A., McClelland, J. W., Holmes, R. M., Zhulidov, A. V., Mull, K., Peterson, B. J., Striegl, R. G., Aiken, G. R., and Gurtovaya, T. Y.: Flux and age of dissolved organic carbon exported to the Arctic Ocean: A carbon isotopic study of the five largest arctic rivers, Global Biogeochem. Cy., 21, GB002934, https://doi.org/10.1029/2007GB002934, 2007.

Reddy, K. R., Kadlec, R. H., Flaig, E., and Gale, P. M.: Phosphorus Retention in Streams and Wetlands: A Review, Crit. Re. Env. Sci. Tec., 29, 83-146, https://doi.org/10.1080/10643389991259182, 1999.
Reimer, P. J., Brown, T. A., and Reimer, R. W.: Discussion: Reporting and calibration of post-bomb ${ }^{14} \mathrm{C}$ data, Radiocarbon, 46, 1299-1304, https://doi.org/10.1017/S0033822200033154, 2004.

Seibert, J., Grabs, T., Köhler, S., Laudon, H., Winterdahl, M., and Bishop, K.: Linking soil- and stream-water chemistry based on a Riparian Flow-Concentration Integration Model, Hydrol. Earth Syst. Sci., 13, 2287-2297, https://doi.org/10.5194/hess-13-22872009, 2009.

Shaw, E. M.: Hydrology in Practice (3 Edn.), Chapman \& Hall, London, 569 pp., 1994.

Shen, Y., Chapelle, F. E., Strom, E. W., and Benner, R.: Origins and bioavailability of dissolved organic matter in groundwater, Biogeochemistry, 122, 61-78, https://doi.org/10.1007/s10533-0140029-4, 2015.

Silins, U., Bladon, K. D., Kelly, E. N., Esch, E., Spence, J. R., Stone, M., Emelko, M. B., Boon, S., Wagner, M. J., Williams, C. H. S., and Tichkowsky, I.: Five-year legacy of wildfire and salvage logging impacts on nutrient runoff and aquatic plant, invertebrate, and fish productivity, Ecohydrology, 7, 1508-1523, https://doi.org/10.1002/eco.1474, 2014.

Spencer, R. G. M., Mann, P. J., Dittmar, T., Eglinton, T. I., McIntyre, C., Holmes, R. M., Zimov, N., and Stubbins, A.: Detecting the signature of permafrost thaw in Arctic rivers, Geophys. Res. Lett., 42, GL063498, https://doi.org/10.1002/2015GL063498, 2015.

Sulzberger, B. and Durisch-Kaiser, E.: Chemical characterization of dissolved organic matter (DOM): a prerequisite for understanding UV-induced changes of DOM absorption properties and bioavailability, Aquat. Sci., 71, 104-126, https://doi.org/10.1007/s00027-008-8082-5, 2009.

Tarnocai, C., Canadell, J. G., Schuur, E. A. G., Kuhry, P., Mazhitova, G., and Zimov, S.: Soil organic carbon pools in the northern circumpolar permafrost region, Global Biogeochem. Cy., 23, GB003327, https://doi.org/10.1029/2008GB003327, 2009.

Tfaily, M. M., Hamdan, R., Corbett, J. E., Chanton, J. P., Glaser, P. H., and Cooper, W. T.: Investigating dissolved organic matter decomposition in northern peatlands using complimentary analytical techniques, Geochim. Cosmochim. Ac., 112, 116-129, https://doi.org/10.1016/j.gca.2013.03.002, 2013.

Tranvik, L. J., Downing, J. A., Cotner, J. B., Loiselle, S. A., Striegl, R. G., Ballatore, T. J., Dillon, P., Finlay, K., Fortino, K., Knoll, L. B., Kortelainen, P. L., Kutser, T., Larsen, S., Laurion, I., Leech, D. M., McCallister, S. L., McKnight, D. M., Melack, J. M., Overholt, E., Porter, J. A., Prairie, Y., Renwick, W. H., Roland, F., Sherman, B. S., Schindler, D. W., Sobek, S., Tremblay, A., Vanni, M. J., Verschoor, A. M., von Wachenfeldt, E., and Weyhenmeyer, G. A.: Lakes and reservoirs as regulators of carbon cycling and climate, Limnol. Oceangr., 54, 2298-2314, https://doi.org/10.4319/lo.2009.54.6_part_2.2298, 2009.

Wang, S., Jin, X., Pang, Y., Zhao, H., Zhou, X., and Wu, F.: Phosphorus fractions and phosphate sorption characteristics in relation to the sediment compositions of shallow lakes in the middle and lower reaches of Yangtze River region, China, J. Colloid Interf. Sci., 289, 339-346, https://doi.org/10.1016/j.jcis.2005.03.081, 2005.

Wauthy, M., Rautio, M., Christofferson, K. S., Forsström, L., Laurion, I., Mariash, H., Peura, S., and Vincent, W. F.: Increasing dominance of terrigenous organic matter in circumpolar fresh- 
waters due to permafrost thaw, Limnol. Oceanogr.-Lett., 3, 186198, https://doi.org/10.1002/lol2.10063, 2018.

Weishaar, J. L., Aiken, G. R., Bergamschi, B. A., Fram, M. S., Fujii, R., and Mopper, K.: Evaluation of specific ultraviolet absorbance as an indicator of the chemical composition and reactivity of dissolved organic carbon, Environ. Sci. Technol., 37, 4702-4708, https://doi.org/10.1021/es030360x, 2003.

Wheeler, J. O, Hoffman, P. F., Card, K. D., Davidson, A., Sanford, B. V., Okulitch, A. V., and Roest, W. R.: Geological map of Canada, Geological Survey of Canada, “A” Series Map, 1996.

Wieder, R. K. and Vitt, D. H. (Eds).: Boreal Peatland Ecosystems, in: Ecological Studies, Vol. 188, Springer Verlag, Berlin Heidelberg, Germany, 1996.

Wickland, K. P., Neff, J. C., and Aiken, G. R.: Dissolved organic carbon in Alaskan boreal forest: Sources, Chemical characteristics, and biodegradability, Ecosystems, 10, 1323-1340, https://doi.org/10.1007/s10021-007-9101-4, 2007.

Wickland, K. P., Aiken, G. R., Butler, K., Dornblaser, M. M., Spencer, R. G. M., and Strigl, R. G.: Biodegradability of dissolved organic carbon in the Yukon River and its tributaries: Seasonality and importance of inorganic nitrogen, Global Biogeochem. Cy., 26, GB0E03, https://doi.org/10.1029/2012GB004342, 2012.

Wilson, R. M., Hopple, A. M., Tfaily, M. M., Sebestyen, S. D., Schadt, C. W., Pfeifer-Meister, L., Medvedeff, C., McFarlane, K. J., Kostka, J. E., Kolton, M., Kolka, R. K., Kluber, L. A., Keller, J. K., Guilderson, T. P., Griffiths, N. A., Chanton, J. P., Bridgham, S. D., and Hanson, P. J.: Stability of peatland carbon to rising temperatures, Nat. Commun., 7, 13723, https://doi.org/10.1038/ncomms13723, 2016.
Winterdahl, M., Futter, M., Kohler, S., Laudon, H., Seibert, J., and Bishop, K.: Riparian soil temperature modification of the relationship between flow and dissolved organic carbon concentration in a boreal stream, Water Resour. Res., 47, W08532, https://doi.org/10.1029/2010WR010235, 2011.

von Wachenfeldt, E., Bastviken, D., and Tranvik, L. J.: Microbially induced flocculation of allochthonous dissolved organic carbon in lakes, Limnol. Oceanogr., 54, 1811-1818, https://doi.org/10.4319/lo.2009.54.5.1811, 2009.

Vonk, J. E. Tank, S. E., Mann, P. J., Spencer, R. G. M., Treat, C. C., Streigl, R. G., Abbott, B. W., and Wickland, K. P.: Biodegradability of dissolved organic carbon in permafrost soils and waterways: a meta-analysis, J. Geophys. Res.-Biogeo., 12, 6915-6930, https://doi.org/10.5194/bg-12-6915-2015, 2015.

Walker, X. J., Baltzer, J. L., Cumming, S. G., Day, N. J., Johnstone, J. F., Rogers, B. M., Solvik, K., Turetsky, M. R. T., and Mack, M. C.: Soil organic layer combustion in boreal black spruce and jack pine stands of the Northwest Territories, Canada. Int. J. Wildland Fire, 27, 125-134, https://doi.org/10.1071/WF17095, 2018.

Zhou, Y., Guo, H., Lu, H., Mao, R., Zheng, H., and Wang, J.: Analytical methods and application of stable isotopes in dissolved organic carbon and inorganic carbon in groundwater, Rapid Commun. Mass Spec., 29, 1827-1835, https://doi.org/10.1002/rcm.7280, 2015. 